\title{
Aorden
}

Nordic Council of Ministers

\section{Innovative Public Procurement and Health Care}

Nordic Lighthouse Project

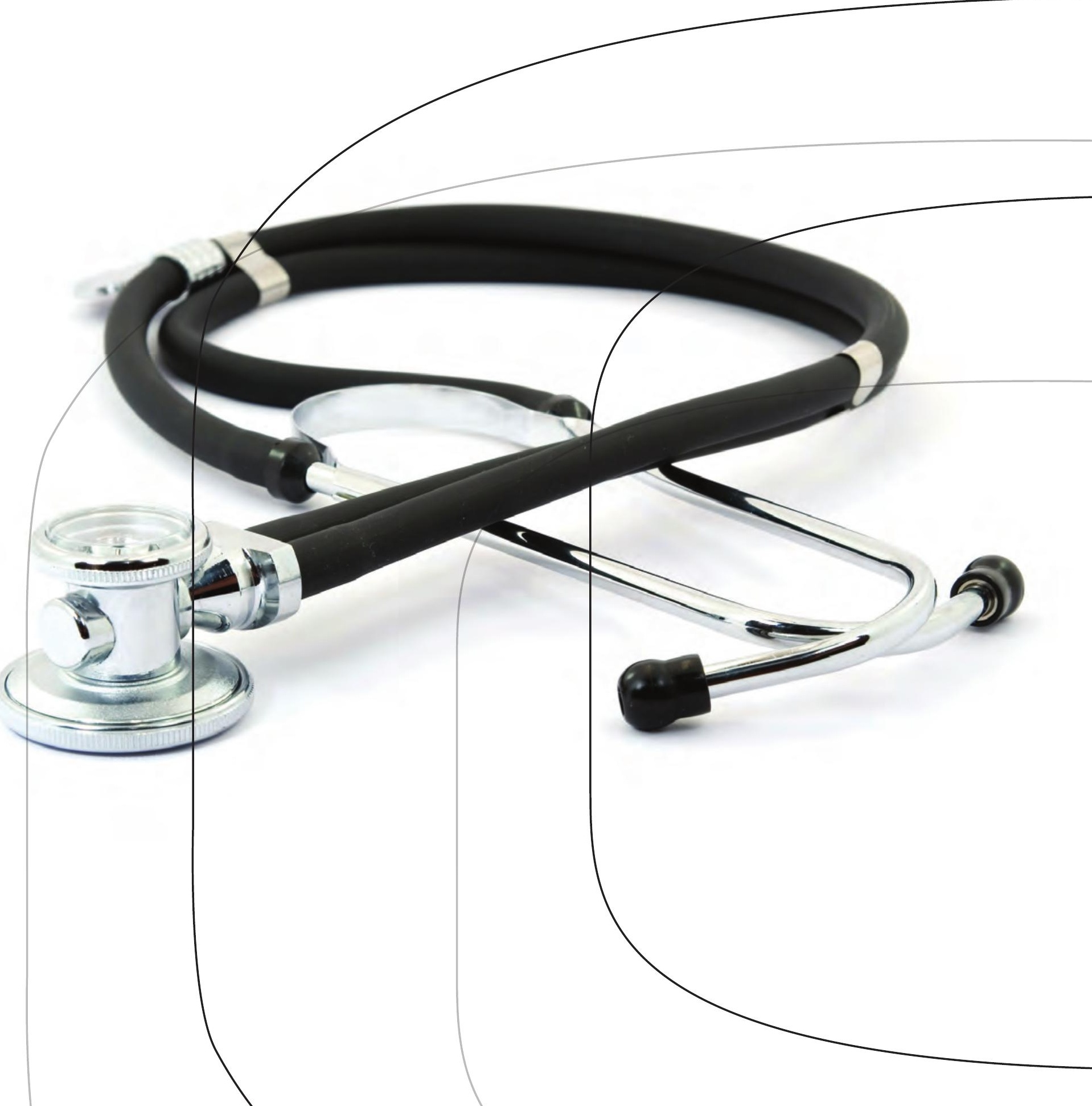


enorden 



\section{Innovative Public Procurement and Health Care}

Nordic Lighthouse Project 
Innovative Public Procurement and Health Care

Nordic Lighthouse Project

TemaNord 2011:567

ISBN 978-92-893-2287-4

(C) Nordic Council of Ministers, Copenhagen 2011

Print: Kailow Express ApS

Copies: 150

Cover photo: Image Selcet

Printed in Denmark

This publication has been published with financial support by the Nordic Council of Ministers. But the contents of this publication do not necessarily reflect the views, policies or recommendations of the Nordic Council of Ministers.

\section{www.norden.org/publications}

\section{Nordic co-operation}

Nordic co-operation is one of the world's most extensive forms of regional collaboration, involving Denmark, Finland, Iceland, Norway, Sweden, and Faroe Islands, Greenland, and Åland.

Nordic co-operation has firm traditions in politics, the economy, and culture. It plays an important role in European and international collaboration, and aims at creating a strong Nordic community in a strong Europe.

Nordic co-operation seeks to safeguard Nordic and regional interests and principles in the global community. Common Nordic values help the region solidify its position as one of the world's most innovative and competitive.

Nordic Council of Ministers

Ved Stranden 18

DK-1061 København K

Phone (+45) 33960200

\section{www.norden.org}




\section{Content}

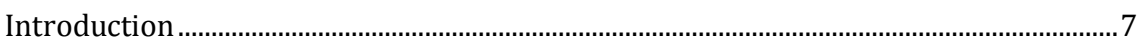

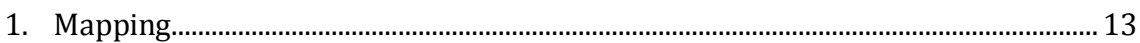

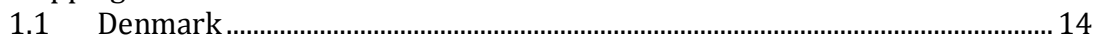

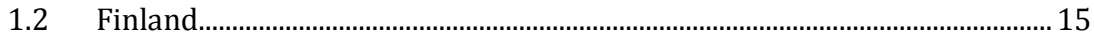

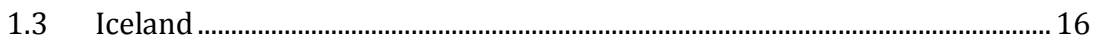

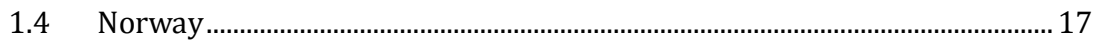

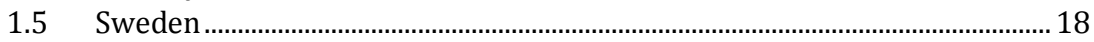

2. Best Practice Cases .......................................................................................................... 19

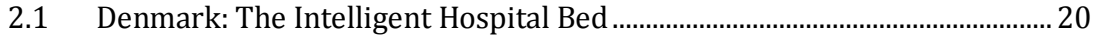

2.2 Sweden: PVC-free blood bags.............................................................................. 24

2.3 Iceland: Core laboratory …………………......................................................... 29

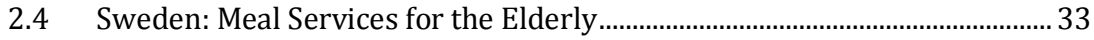

2.5 Finland: Supported Housing Services .................................................................. 37

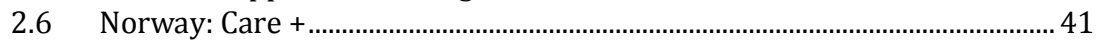

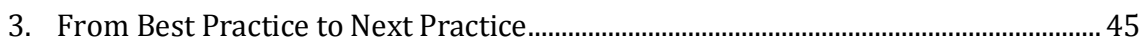

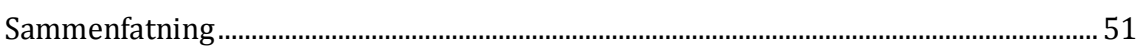

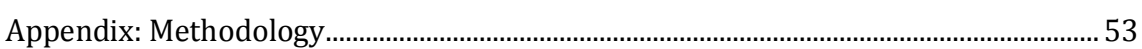





\section{Introduction}

This report concerns innovative public procurement in health care in the Nordic countries. The focus of this report is therefore on procurement differing from traditional procurement in the way it is processed and the content of the procurement. Innovative procurement is considered more demanding than traditional procurement as it contains more barriers and complications. Hence, there is a need for further analysis. One of the central knowledge gaps concerns the lack of best practice examples that can illuminate how the barriers and complications can be overcome.

It is the goal of this study to help shrink the knowledge gap by presenting a few selected cases that exemplify best practice from innovative public procurement in health care in the Nordic countries. The report has been prepared by DAMVAD.

\section{The public sector plays an important role}

The role of public procurement as a means to stimulate innovation has been emphasised increasingly during the last decade. The public sector has a key role when it comes to procurement of health care in the Nordic countries as health services are a public good. 80 to 85 per cent of health spending in the Nordic countries is funded by public sources ${ }^{1}$. Thus public agencies have been described as "big market players" having "powerful means to stimulate private investment in research and innovation"2. Consequently, the public sector commands a strong purchasing power which, if managed accordingly, could promote innovation.

The public sector is the main source of health funding in all the Nordic countries. This is illustrated in figure 1. As each country has large expenditures on health care, accordingly there is a great potential in making health care more efficient and to achieve more quality from the money spend. Subsequently, there is a challenge awaiting across the Nordic countries regarding the aging population which will increase the pressure on spending. Hence, there is an overall incentive to use innovation as a way to find solutions to these challenges.

\footnotetext{
1 OECD data presented in "Health Innovation in the Nordic Countries", DAMVAD for The Nordic Council of Ministers.

${ }^{2}$ Rolfstam 2010 p. 1, and the European Commission, 2005, p. 8
} 


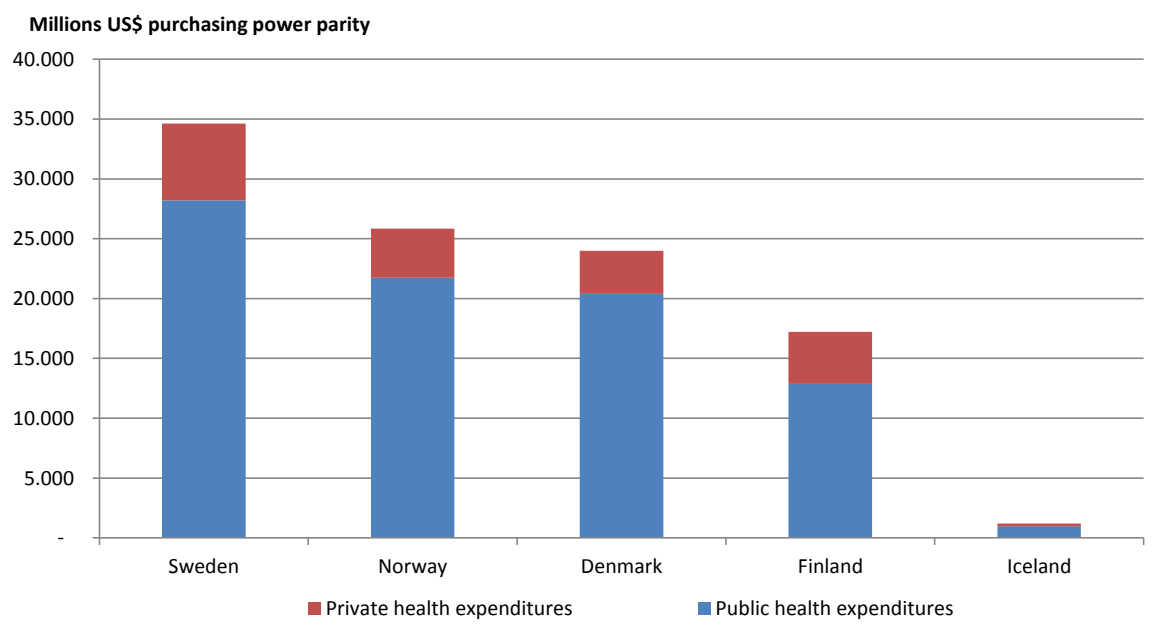

Figure 1: Public expenditures on health care

Source: DAMVAD 2011 based on data from Statistics Iceland, Statistics Sweden, Statistics Denmark, Statistics Norway, Statistics Finland and EUROSTAT data on purchasing power parities (2009)

\section{Towards a definition}

Public procurement that is to drive innovation differs from traditional procurement. Overall, there are two central approaches to where innovation is included in procurement in the health sector.

Innovation procurement when the purpose of the procurement is to ensure a product or service that is new or significantly improved compared to existing products or services

Innovative procurement when the procurement process that surrounds the procurement is done in an innovative manner, meaning that the process itself has been organised in a new and improved way.

The study includes both approaches to innovation and procurement as it is the perception that in most innovative procurements there is a correlation of the two dimensions.

Connected to the two approaches or dimensions of innovation in the procurement process is the role of the public sector. Because it is the public sector that shapes the form of demand in tenders, the perception of the public sector as a demanding client is very crucial to the way tenders are composed and thus the process of procurements. Therefore, another concept which is emerging is the notion of intelligent public demand where government agencies and public institutions can stimulate innovation through procurement.

The public demand can take different forms according to how the public sector formulates its need which the procurement is supposed to solve. In the figure below, the different positions which the public sector can take through their demand is demonstrated. The different positions also indicate to what degree the public sector stimulates procurement of innovation and innovative procurements relating to the specifications of the need in the procurement process. 
Figure 2: A continuum of procurement and innovation

Source: DAMVAD 2011 based on scientific work of Max Rolfstam (2010) and Charles Edquist (2009)

The basic premise behind the model is the role of the public sector related to the way tenders are specified and how the public sector defines the task central to the procurement situation. If the public sector through specifications in the procurement process demands a specific need without defining more specifically how the content and final solution should appear, there is room for innovation.

The model also depicts the traditional procurement situation when a public organisation buys ready-made products or services where the solutions is known up front, and where price and quality are the main criterions leaving less room for innovation. At the bottom of the figure above, it is indicated that the public sector may specify just their need (e.g. a new type of blood bag with a reduced amount of PVC) or an end goal (e.g. less people getting infections based on harmful toxics in the material). The purpose is then to get suppliers' input to how those needs and wants can be met. It is also in this kind of tenders that room for innovation is significantly increased.

The study presents different approaches to the design of an innovative procurement process. Below are listed some of the key terms applied in the study:

- Standard tendering - a formal procurement method where invitations to tenders are sent out with specified content, bids received and evaluated, and a contract is awarded. This typically involves the formal EU procedures regarding open tendering or restricted tendering procedures. 
- Competitive dialogue - a procurement method used in complex procedures when the public institution is not able to objectively define the technical means that should be met in the tender. Competitive dialogue gives the public institution the possibility of engaging in dialogue with suppliers. This concept is a formal EU tendering procedure.

- Pre-commercial procurement - an approach to procuring R\&D services which enables public procurers to share the risks and benefits of designing, prototyping and testing new products and services with the suppliers, without involving State aid.

It is important to make a distinction between types of specifications of demands as illustrated in figure 2 and the three key terms. Competitive dialogue and standard tendering can be used for several specifications of demands, and as such the concept of pre-commercial procurement can be implemented through competitive dialogue. ${ }^{3}$

\section{There are barriers associated with innovative procurement}

As innovative procurement differs from standard procurement there are different challenges and barriers associated with this kind of procurement. This is evident from searching the literature and through insights gained in interviews with experts and practitioners ${ }^{4}$. The following presents some of the main barriers highlighted.

\section{Navigating the legal framework}

The legal framework in itself is not an obstacle to innovative procurement, however, the national interpretations are. Furthermore, the procurement laws are complex and it requires profound legal competences to safely navigate within the legal framework. As innovative procurement is still a relatively new phenomenon within health care in the Nordic countries, there are few precedent legal interpretations to rely on.

\section{Limited use of dialogue}

A key challenge to innovative procurement is that only few actors are using dialogue as a part of the procurement process. Furthermore, there are uncertainties related to how and at what stage in the process that dialogue can take place without compromising procurement rules.

\section{Budget constraints}

There are budget constraints on health care expenditures in the public sector. This results in a dominant focus on price in procurement prac-

\footnotetext{
${ }^{3}$ EU-commission (2008): Pre-commercial procurement

${ }^{4}$ Based on Affärs Concept in Stockholm AB (2008), Vinnova (2009), Rolfstam (2010), FORA (2010) and interviews with procurement experts and practitioners (see Appendix).
} 
tices and leaves very little room for using resources to create incentives for innovative procurement.

\section{Lacking incentives for innovation}

Incentives for innovation through procurement are not always a priority of top management in public organisations and a culture of "zero-mistakes" reduces the incentives to innovate. Internal budgets at hospitals create crossing incentives for innovation through procurement as expenditures and savings are distributed to different units.

\section{Limited innovation competences in procurement units}

A key challenge to innovative procurement is associated with the competences available in procurement units. In order to embark on innovative procurement it requires different legal competences than standard procurement as well as an understanding of health innovation such as identifying user needs and specifying functions of solutions. The size of procurement units influences the composition of competences and thus the power in purchasing.

\section{Risk aversion}

Innovative procurement is inherently more risky than traditional procurement which activates the need for risk management as part of the process. Hospitals and other health public procurement organisation are not encouraged to take risks, or consider value for money in their procurement decisions. Instead the focus has been on obtaining a "safe" standard product at the lowest price.

These main challenges relating to innovative procurement will be central to the presentation of best practices. The main focus of the case presentation will be to focus on how they have dealt with these challenges. The main topics of the cases will be the legal framework, incentives, risk management and dialogue as these themes are central regarding the handling of challenges in innovative procurement. The cases have been selected based on their ability to handle challenges and to find a viable solution. 



\section{Mapping}

Overall public procurement of innovation has gained increased attention from policymakers in the Nordic countries.

The national market and the key public procurers within the health sector affect and set the frames for innovative procurements. As it is known from the market in the private sector, demand is central to the supply of goods and services. Because health care is a public good in the Nordic countries, the role of the public sector is central as it indeed shapes demand.

One key factor related to this is the size of the procurers. It is essential for public procurement how large and qualified the public buyers are. Large public buyers encompass large demand and critical mass when buying, which makes it possible to obtain economies of scale resulting from large scale production. Furthermore, it is possible to have specialised skills in the procurement work force that may lead procurement decisions further than standardised solutions. However, if the procurement is standardised, e.g. due to national framework agreements, it could entail that only large scale standard solutions are in demand, because of the lack of differentiated demand. Thus, it is estimated that a diversified demand for health care products and services could be a driving force for new innovative solutions. The more different and specific needs needing to be covered through procurement, the more necessary it will be to have different user needs reflected. However, a sufficient critical mass in demand is still necessary to ensure that there is a sufficiently strong incentive in the development process.

Table 1 below summarises the key players within public procurement in the health sector in the Nordic countries.

Table 1: Key Nordic public purchasers

\begin{tabular}{|c|c|c|c|c|}
\hline \multirow[t]{2}{*}{ Country } & \multicolumn{3}{|c|}{ Procuring organisations } & \multirow[t]{2}{*}{ Market characteristic } \\
\hline & National & Regional & Local & \\
\hline Denmark & SKI & 5 Regions & 98 municipalities & Centralized \\
\hline Finland & Hansel Ltd. & 20 Hospital districts & 336 municipalities & Highly fragmented \\
\hline Iceland & State Trading Centre & $\begin{array}{l}7 \text { health institutions } \\
\text { and Landspitali }\end{array}$ & Health institutions & Centralized \\
\hline Norway & $\begin{array}{l}\text { Procurement services } \\
\text { for Health Enterprises }\end{array}$ & $\begin{array}{l}4 \text { Regional Health } \\
\text { Authorities }\end{array}$ & 430 municipalities & Fragmented \\
\hline Sweden & $\begin{array}{l}\text { SKL Kommentus } \\
\text { inköpscentral }\end{array}$ & $\begin{array}{l}17 \text { county councils } \\
\text { and } 4 \text { regions }\end{array}$ & 298 municipalities & Highly fragmented \\
\hline
\end{tabular}

Source: DAMVAD 2011 
As illustrated above there are differences to be found in the way the five Nordic countries organize their procurement. In all the countries procurement is carried out by both the regional players and municipalities however with different size of the players. In Norway, Sweden and Denmark the division between the regions and municipalities are somewhat similar as procurement within health care is conducted primarily by the regions that procure all products and services related to hospitals and primary care including medical services such as ambulances and doctors. Municipalities procure products and services related to primary health care. The municipalities in Finland play a bigger role in procurement than what is the case in the other Nordic countries.

In Norway and Denmark the majority of procurement within the health sector is carried out by a few rather large players, whereas procurement in the other Nordic countries is rather fragmented and handled by small buyers. Iceland also has centralised purchasers primarily consisting of the main hospital in Reykjavik, Landspitali which is still a relatively small player. Although there are examples in Norway, Sweden and Finland of joint procurement and collaboration between municipalities as well as between regions and municipalities, joint procurement seems to be more the exception than the norm.

The following looks into the market of innovative public procurement in each of the Nordic countries.

\subsection{Denmark}

\section{Procurement in the Danish health sector}

Regions in Denmark are the key purchasers within the health sector. The regions collaborate within public procurement and there are several committees to support the cross-regional collaboration within public procurement. An effort has been made to further centralise the procurement efforts. For this purpose, the regions have developed a secretariat, Strategic Purchase (Strategisk Indkøb), to establish close interaction between the regions with the goal of knowledge sharing and buying larger quantities together.

The municipalities are responsible for primary health care. They have organised their health efforts structurally in different set-ups, and there is no central organ facilitating joint procurement. Procurement of items not relating directly to health care is covered by the National Procurement Association (SKI).

\section{Innovative procurement in the Danish health sector}

In Denmark there is a political focus and ambition to support innovation as part of the procurement practices. The potentials in in-innovative procurement have been highlighted as a way to ensure economic growth through new inventions. Procurement has also recently been highlighted in the government foundation of the new government in Denmark. 
Interviews with procurement practitioners, however, underline that there is a difference in the way the potentials in procurement practices are articulated by politicians and the procurement practices that must adhere to other political agendas such as cost cutting. Cost effectiveness is indeed prevailing as the regions are required to complete savings for 1 billion DKK. Thus public procurement within the health sector in Denmark is intensively focused on price and value for money as part of the budget challenges.

Nevertheless, the regions all attempt to include innovative elements in procurement processes and experiment with more open procurement processes. However, the experience with collaboration projects is more widespread than the experience with innovative procurement. This is also seen through the establishment of the "Laboratory of public-private innovation and welfare technology" which is a cross-regional initiative focusing on providing guidelines for collaboration on innovation as well as ensuring the integration of the public procurement units as part of the innovation projects.

As an attempt to further increase innovative procurements, the Business Innovation Fund has focused some of its funds on financial support to procurement of pre-commercial solutions. The fund supports the initial phases of procurement to do studies on the potentials in changing the procurement process and which processes are necessary to include.

\subsection{Finland}

\section{Procurement in the Finnish health sector}

The municipalities play an important role in the provision of health care services in Finland. By law the municipalities have the main responsibility for providing health care. The municipalities all belong to a hospital district.

Municipalities as well as hospital districts carry out procurement. There are examples of joint procurement between the hospital district and the municipalities that belong to the hospital district. One example is from the Hospital District of Helsinki and Uusimaa where the districts purchase the medical consumables whereafter the municipalities buys directly from the hospital district. Procurement between hospital districts is however not yet that common in Finland.

\section{Innovative procurement in the Finnish health sector}

At the policy level there has been an increased focus on promoting innovation through public procurement. Finland's national innovation strategy, drafted in 2008, emphasises user-driven innovation and demanddriven innovation policies as a way to promote innovation, and the innovation strategy defines public procurement as a demand driven innovation policy tool. 
At the moment innovative public procurement within the health sector is still at the start-up phase. Experts and practitioners point out that unlike in Denmark and Iceland the lack of innovative procurement is not due to limited budgets, but due to prevailing risk aversion among public agencies as well as lack of knowledge, experiences and best practice examples.

The Finnish national innovation funding agency, Tekes, is currently running a programme aiming to promote innovations in public contracts by means of funding, networking and cooperation between different actors. As part of the programme public procurement units and public utilities can apply for funding for public procurement of innovations. In the first stage, planning of procurement, Tekes funds up to 75 per cent of the total expenses in a single project. In the second stage, procurement or implementation, Tekes provides funding support for the procurer and for suppliers' research and development expenses.

\subsection{Iceland}

\section{Procurement in the Icelandic health sector}

Iceland is divided into seven health care regions, each with their own primary health care centres, some of which are run jointly with the local community hospital. All procurement units in health organisations (hospitals, clinics, elder homes etc.) are run as autonomous units that, within defined frames designed by the Ministry of Welfare and Ministry of Finance, are responsible for the procurement for the specific unit.

The main hospital in Iceland, Landspitali, is due to its size and central function responsible for approximately 90 pct. of the total procurement within health care that is related to daily hospital consumptions. Landspitali negotiate deals on the supplies that benefit from buying in bulk. It is up to the hospitals and health care institutions whether they wish to buy from Landspitali as oppose to buying directly from the suppliers. The majority of procurement units in Iceland combine their purchase from both Landspitali and from suppliers directly. Procurement of larger units is mainly handled by the individual procurement units themselves.

In actual health care procurement there is collaboration between the health care institutions and the State Trading Centre (Ríkiskaup). Tenders are sent to Ríkiskaup that looks through them to assess the legal elements and subsequently they announce the tender. Propositions from bidders are assessed by the procuring unit.

\section{Innovative procurement in the Icelandic health sector}

The economic crisis in Iceland which started in 2008 has had several effects. With large current budget deficits it is necessary to find ways to economise the spending in the public sector. As part of this, there have been initiatives to identify ways to increase the efficiency in the public procurement in Iceland. 
It has been identified that there is a need for an organisational changes in the organisations carrying out procurement. In particular, there is a need to change the rules in order for health organisations to be able to combine their purchasing power and get discounts in their procurements based on inspiration from Denmark and Norway. It is currently under consideration if Iceland too, should establish a similar structure with the main purpose of combining the strengths in the purchase.

The current focus on cost cutting and efficiency does not indicate lack of interest in using public procurement to stimulate innovation. It is the intention that a restructuring of the procurement organisations will lead to better competencies in the procurement units and this will also help release resources to innovation.

\subsection{Norway}

\section{Procurement in the Norwegian health sector}

In Norway the regional health authorities are responsible for the hospitals. Hospital procurement is carried out by three different procurers. Local procurement is executed by the Hospital trust, regional by the Regional Health Authorities and national by Procurement services for Health Enterprises. Coordinating these purchases in a centralised function represents several advantages. Some of the advantages are lower prices due to higher volume, product standardization, higher quality, and more reliable deliveries. Additionally, the centralised procurement unit allow for Norwegian Health Authorities to purchase equipment, goods and services.

The municipalities are responsible for providing primary health care and social services. Procurement related to the municipalities is carried out by each individual municipality.

\section{Innovative procurement in the Norwegian health sector}

A lot of positive steps have been taken to strengthen innovation in the health sector in general and the collaboration between public and private parties in particular. This is evident in the clear strategies, public measures and establishment of bodies specialised in enhancing and supporting innovation. Interviews with Norwegian experts and practitioners indicate that the increased focus on innovative procurement has been urgent as there previously has been limited focus on innovation in procurement.

One of the current initiatives to promote innovation in procurement is the establishment of a national programme (Leverandørutviklingsprogrammet) aiming to increasing public private collaboration and innovative public procurement. The programme was established in 2010 by The Confederation of Norwegian Enterprise (NHO) and The Norwegian Association of Local and Regional Authorities (KS) with participation of key players such as Innovation Norway, the Agency for Public 
Management and eGovernment (Difi) the Ministry of Trade and Industry among others. The objective is to stimulate a different use of public procurement as a means to ensure innovation and increase the understanding and knowledge about public procurement. Two of the central elements in the program are 1) upgrading the competences at procurement units and 2) ensuring dialogue in the procurement process.

\subsection{Sweden}

\section{Procurement in the Swedish health sector}

The county councils and regions form the basis of the Swedish health care system. They are responsible for hospitals and health centres. On a local level the municipalities are responsible for primary care and the procurement associated with this task.

The majority of the public procurement within health care in Sweden is conducted by the county councils and regions. There is some cooperation and joint procurement between them. However this is mostly related to standard products, where they collaborate in order to increase demand and thereby lowering the price. When it comes to complex procurements, most county councils and regions do their own procurement. In some cases the county councils and regions also conduct joint procurement with the municipalities in their area.

\section{Innovative procurement in the Swedish health sector}

The political interest in using public procurement as a demand instrument to stimulate innovations in the health sector is rising in Sweden. Over the years, many efforts have been made to promote innovative procurement especially within the energy sector, and several initiatives and investigations have been carried out.

Over the last years, Vinnova, the Swedish Governmental Agency for Innovation Systems, has actively tried to promote innovative procurement through different programmes. The latest programme, Innovationsupphandling, was launched in 2011. It aims at enhancing and developing innovative procurement and the use of pre-commercial procurement.

The use of innovative procurement in the health sector is still in the start-up phase. At a regional level steps are taken in order to promote innovative procurement. Currently the region, Region Skåne, is carrying out a number of pilot cases in order to gain experiences on how the procurement process has to be designed in order to promote innovation. The region is also working towards setting goals for the number of innovative procurements that are to be carried out within a certain time frame.

The Swedish Association of Local Authorities and Regions (SKL) is also working to spur innovative procurement by setting up networks and promoting knowledge sharing and the dispersion of best practice examples. SKL has recently started up a network on innovative public procurement. 


\section{Best Practice Cases}

This section presents the selected cases expressing examples of best practice within innovative public procurement in health care in the Nordic countries. In total, six cases have been selected with a representation of all Nordic countries.

The cases have been identified based on a peer-reviewed process where procurement experts and practitioners in the Nordic countries through interviews and a survey have identified which actors are leading the field within innovative procurement in health care.

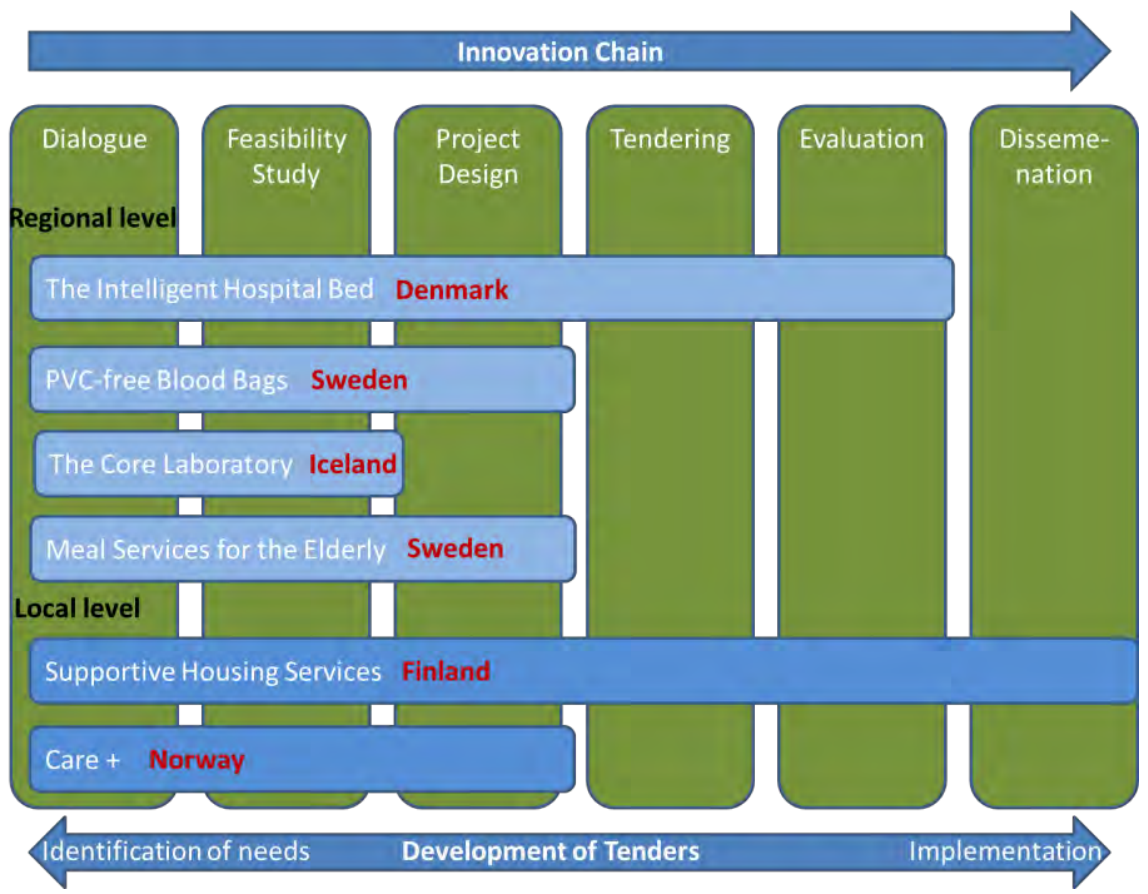

Figure 3: Best Practice Cases

Source: DAMVAD 2011

As the purpose of the selection has been to identify examples of best practice and not just examples of completed innovative procurement, the selected cases represent different levels within the procurement process. The figure above presents the different steps in an innovative procurement process. The innovation chain comprises steps from identifying needs towards the implementation of a new or improved product or service through a tendering process. Whereas some of the steps in the process differ from case to case, they demonstrate the most common steps identified. As illustrated in the figure, some of the selected cases are in the initial phase whereas others are close to or have been implemented. Furthermore, the selected cases represent both the regional and local levels. 


\subsection{Denmark: The Intelligent Hospital Bed}

\section{Introduction}

The intelligent hospital bed was initiated by a forward-looking director of nursing at Randers Hospital in the Region of Central Denmark who wanted to develop a hospital bed that catered to the needs of both patients and hospital staff. Early in the process, however, it was acknowledged that what had started as collaboration on innovation had to be converted into an innovative procurement process in order to not coincide with procurement laws. In fact, the innovation project concerning the hospital bed was almost terminated before it even got started due to the procurement rules in regards to public private collaboration on innovation. This case is now known as best practice because:

- It surmounted the challenges related to crossing untouched legal territories and found a viable solution

- It is a point of reference in Denmark as to how innovative procurement processes can be completed despite lack of legal support from government authorities.

The procurement process was designed around elements of competitive dialogue. The process included an information meeting about the use of competitive dialogue as a procurement method, a dialogue conference with interested companies, a project design covering the specifications for the tender, the evaluation of incoming bids and the award of the contract. The process is currently at a stage where a prototype of the beds is being developed and will be ready for testing in the beginning of 2012 with a following implementation at the hospital. The steps in the model are depicted below.

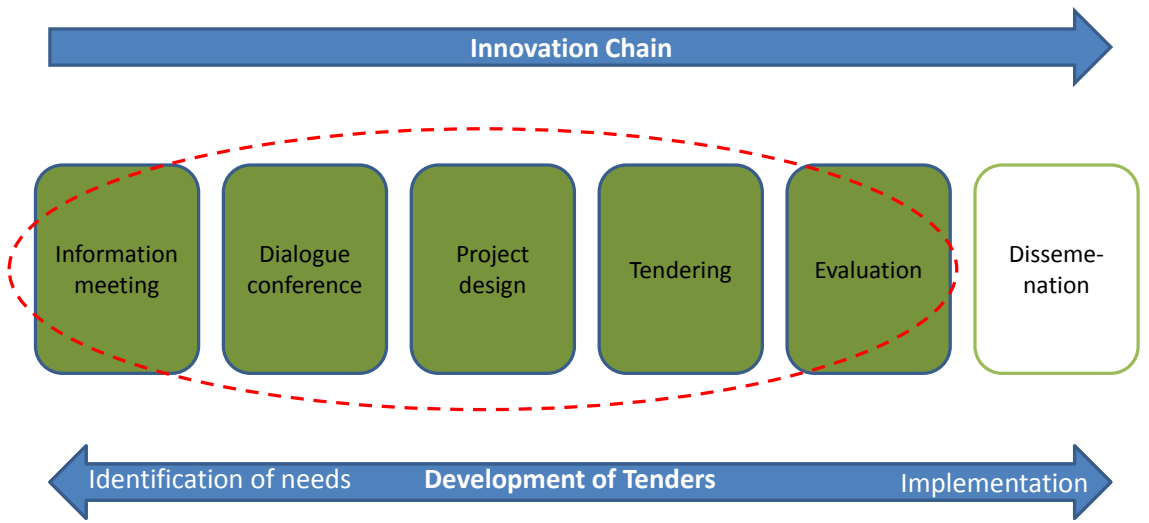

Figure 4: Procurement stages

Source: DAMVAD 2011

\section{Legal framework}

The legal framework initially served as a constraint to the project because it had started as an innovation project without considering the legal 
boundaries of public procurement. Early in the process, it was acknowledged that once the development phase was over and the order release came, the beds would most likely exceed the legal threshold and hence call for an open procurement process not guaranteeing the possibility to purchase the developed bed. Hence the design of an innovation process that took procurement rules into consideration was a legal and formal necessity. From the involved public parties there was great fear of anticompetitive behaviour that could be the result of a tendering process that would award the tender to the companies participating in the development process. These considerations were presented to the Danish Enterprise and Construction Authority and the Competition and Consumer $\mathrm{Au}-$ thority to receive guidance on the interpretations of the legal framework. They recognised the problem, but were not able to give their endorsement or clear directions as to how the hospital should proceed.

The legal framework emerged as an enabler of the potentials once legal advice and endorsement from a privately hired lawyer was included in the process. Hence, key learning points regarding the legal framework relate to:

- The necessity in having legal guidance and endorsement as part of the innovative procurement process

- If public authorities are unable to provide their endorsement, legal counselling must be obtained from other sources

- It requires a lot of resources as both time and money is spent on unravelling the legal framework

- Additional costs of buying legal assistance could have been reduced or even prevented through action of government authorities.

\section{Process and Dialogue}

To address knowledge gaps, the procurement process was initiated by an information meeting with the purpose of clarifying the need that the procurement process at hand should address, and to explain the use of competitive dialogue in health care. Subsequently, a dialogue meeting with interested companies expressing their considerations for the design and development of the bed was conducted. The region established contact with the companies by announcing the tender at the homepage of the region through EU channels.

Next step in the process was the tender itself. The hospital, the region and the lawyer developed this tender in collaboration, and since there had been no previous examples of this kind of procurement process, the tendering documents were made from scratch. The most crucial aspect of the tendering process was the clarification that Randers hospital would buy 24 hospital beds, with an option to buy more at a later stage. The option is also valid for the other hospitals in the Region of Central Denmark that could buy the hospital beds for the price negotiated in the process.

Only one consortium of companies made a final bid for the bed and a partnering contract was negotiated between the consortium and the 
region. In close cooperation between the consortium and the hospital, the new and innovative hospital beds are being developed. Key learning points refer to:

- In Denmark competitive dialogue is not that common a tool within procurement in health care. Thus there is an information need concerning the possibilities in using dialogue and the expectations towards the participation of the companies that must be addressed

- The process has led to a restructuring of the organisation now catering to innovative procurement by having procurement officers and innovation agents in the same unit

- The region required a consortium of companies to make the bid which is anticipated to have reduced the amount of bids.

\section{Incentives}

Several incentives have driven the process forward. There have been both individual and overlapping incentives.

The hospital's incentive was the prospect of getting a hospital bed that would meet the needs of patients and staff by including modern technology. Another motivational aspect relates to the outlook of getting a bed that would assist hospital staff in the daily care releasing time for other tasks concerning the well-being of patients and thus also giving the patients a higher quality of life while being at the hospital. Along this line was also the expectation that in time, the new hospital bed could help make the hospital admission more efficient and thus increase the operation optimisation.

The incentive from the Region of Central Denmark to finance the project was to manifest the region's profile as an innovative region within health care. Along with the profiling, an incentive for the region was also to contribute to the creation of jobs in the region.

The region has deliberately worked to ensure a clear incentive for the participating companies. This has been done by securing the first sale of beds with the hospital as the first buyer. It is included in the tender that the hospital will buy 24 beds with an option for the Region to buy more at a later stage. The inclusion of the guaranteed first sale in the tender has been done without compromising procurement laws. This possibility has been the key to success as the companies have had a demand for the beds from the beginning. A related incentive for the companies is the ensured proof of concept provided by the collaborating hospital. The proof of concept provides the possibility of selling the innovative hospital beds to all hospitals in Denmark and with an export potential. The main key learning points are:

- The effort in securing an incentive for the companies through the first sale to the hospital has been the key to success for the project. 
- The first sale to the hospital as a part of the tender has been the securing of a mutual incentive as it has also ensured that the hospital was able to buy the beds without compromising procurement rules.

\section{Risk management}

Overall, the approach to risks in the process has been to deal with them as they emerged. From an early point it was clear to the participants that since the process had not been attempted before, a line of unforeseen risks were likely to emerge. Despite the fact that no formal approach to risk management was developed in the process, a few key learning points emerged:

- The continuous dialogue with procurement lawyers served as a way to deal with the legal risks proactively.

- The partnership contract established between the consortium and the Region defined and dealt with risks of replacing participants in the consortium

- Financing from both the public and private side has created a joint commitment to the completion of the process.

\section{Key learning points}

The overall learning from this case relates to the pioneering work of finding a legal solution to how innovative procurement could be conducted in relation to the development of the new hospital bed. Despite the lack of endorsement from government authorities to their choice of procurement model, a solution was found and is a point of reference within health care in Denmark.

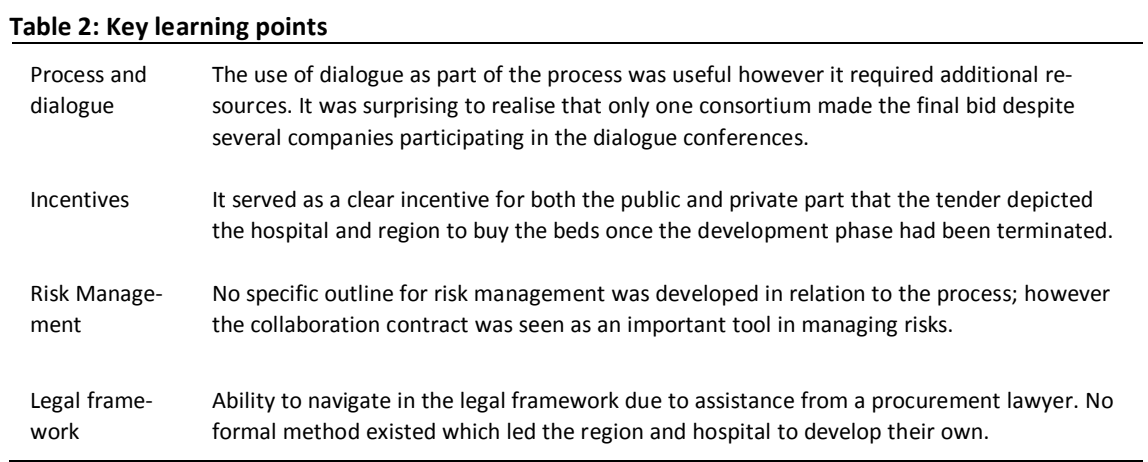




\subsection{Sweden: PVC-free blood bags}

\section{Introduction}

Annually 450,000-500,000 conventional PVC-blood bags are used in Sweden. Approximately 30-40 per cent of the bags consist of the DEHP plasticizer, which is classified as a reproductive toxin. Research shows that DEHP can leach out of the bag thus exposing patients to the toxin. Replacing the current blood bag with a PVC-free alternative would create a substantial decrease in DEHP flow. An innovative procurement project was launched to explore the options and include the different stakeholders relevant to the completion of substitution of traditional blood bags with a new PVC-free version.

This case is known as best practice because:

- It is one of the pioneering innovative procurement projects within the health sector in Sweden

- It demonstrates how insights from scientific research can be transferred to an innovative procurement process.

As the figure below highlights, the project's activities included forming a purchaser group, conducting a feasibility study and setting a requirement specification. The activities relied on each other and have been run in parallel. Vinnova financed the project as part of their Innovative Procurement Programme.

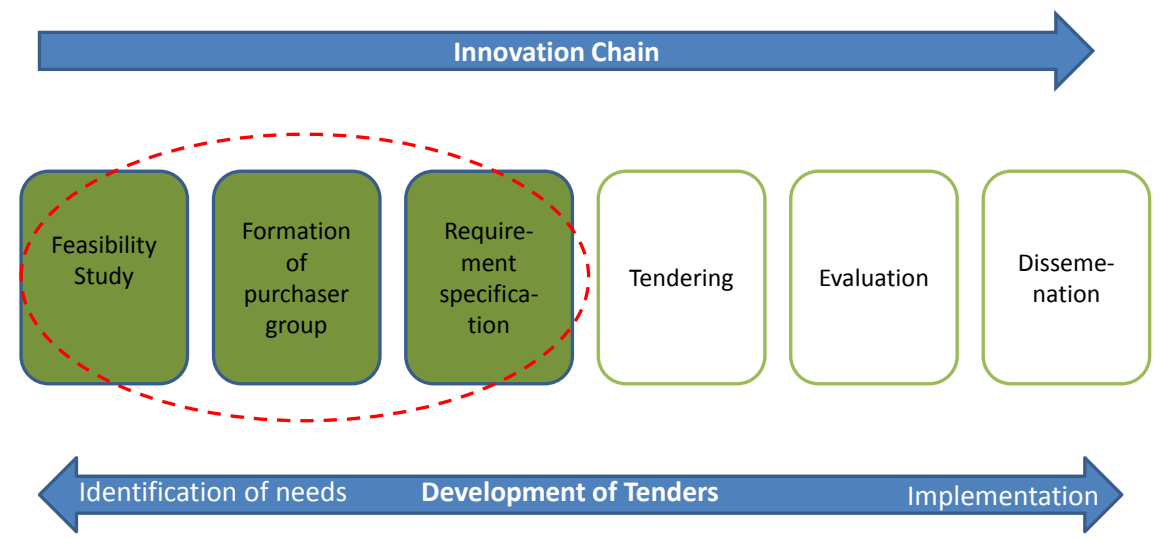

Figure 5: Procurement stages

Source: DAMVAD 2011

Originally, the procurement phase was scheduled to take place at the end of the identification phase. However, early in the process, it was recognised that procuring a new blood bag was complicated since it is a complex product controlled by a strict regulatory environment and associated with a long development timeline and large research and development costs. It was therefore decided that the most suitable way to move forward was with a demonstration project. Subsequently, Jegrelius Institute for Applied Green Chemistry applied for and recently received 
funding from the EU Life+ programme to carry out a demonstration project. The purpose of the demonstration project is to remove the barriers associated with the introduction of a PVC-free blood bags. Another important element is expanding the purchaser group and increasing the awareness of the need for a PVC-free blood bag. 5

\section{Process and Dialogue}

The formation of the purchasers group was facilitated through an existing national group that works with phasing out chemicals from healthcare products. The purchasers group consisted of representatives from the majority of county councils and regions in Sweden and was reinforced by experts in eco-toxicology, market and innovation, polymer chemistry, testing medical devices and blood transfusion medicine. The financing from Vinnova ensured that the necessary expertise and competencies could be brought into the purchaser group

The feasibility study undertaken consisted of a number of studies. First and foremost it was investigated what already existed on the market, what had already been tested, and problems encountered previously were highlighted. A thorough market analysis was also undertaken in order to understand the market potential for developing a suitable replacement product.

Different alternatives for proceeding after the specification phase were also compared as regards their advantages and disadvantages. One of the procurement alternatives that were investigated was precommercial procurement. It was however determined that this was not the best way to move forward as pre-commercial procurement involves risk-benefit sharing which meant that the public health organisations would have to invest a relatively large amount of money in the research and development process. Innovative procurement was their most feasible way to move forward, had the project been able to move on to the procurement phase. This relied on the ability to bundle demands and to use of financial incentives that presented the suppliers with an interesting market and, to some extent, lessened the risk associated with R\&D.

Finally, the feasibility study listed the potential manufacturers. In order to understand the manufacturers' perspective, two rounds of meetings were held with manufacturers. All manufacturers that were identified as active on the Swedish market in the market study, were invited. The expert in testing medical devices and blood transfusion medicine also had an on-going dialogue with the manufacturers throughout the project.

In setting the requirement specification, the purchaser group started with a specification requirement for a standard blood bag and then reformulated it. The objective was to set a realistic requirement specifica-

\footnotetext{
5 The demonstration project will be carried out by Karolinska University Hospital and four European companies. All four companies are active in the plastics business at different stages of manufacturing. For more information about the project see http://www.pvcfreebloodbag.eu/.
} 
tion and a workshop was held with the manufacturers to present and discuss the suggested demands in order to receive feedback on the preliminary specification of requirements. Dialogue with the manufacturers entailed adjustments in the requirements.

Key learning points are:

- The set-up of a purchasing group with experts in all fields ensured indepth knowledge in the group

- Financial support ensured that the necessary expertise and competencies could be brought into the project

- Dialogue with the manufacturers gave crucial information to set a realistic requirement specification as well as information on the possibility to carry out procurement.

\section{Legal framework}

In order to get an understanding of the possibilities, the existing legal framework provide for performing an actual procurement of a PVC-free blood bag, procurement alternatives and the legal framework was investigated by a legal consultant. A main issue in this study was to investigate the possibility to provide financial incitements and reduce risks.

The study showed that the legal framework was not an obstacle in itself. However, the study highlighted that there are no clear rules as to when and how financial incentives can be used to spur the development of a PVC-free blood bag. There was no provision found in the Public Procurement Act that explicitly prohibits the use of financial incentives. It was, however, unclear how the Swedish Local Government Act stating that support to individual companies cannot be given unless there are very strong grounds for doing so, should be interpreted. The issue was never resolved as the project never moved on to actual procurement and the need to provide financial incentives was no longer relevant.

The procurement units located in the county councils and regions most likely had some of the competencies and the knowledge required to undertake a study on the possibilities within the legal framework, but due to lack of resources an external consultant carried out the study. The financing of the study arrived from Vinnova as a way to assist the completion of an innovative procurement process. The fact that a study clarified the options within the existing legal framework made it more clear how to precede and where the conflicts were in the framework. Hence, key learning points are:

- Legal guidance and endorsement is an important element in an innovative procurement process if the process is to be in line with the legal framework.

- There are no clear rules in the legal framework as to when and how financial incentives can be used to spur innovation. 


\section{Incentives}

Several of the county councils and regions had already been working towards phasing out PVC for a number of years and the outlook of getting the possibility of purchasing a PVC-free blood bag served as a clear incentive to their participation. Another incentive for the county councils and regions' participation was to gather knowledge on how to perform innovative procurement helpful to their further aspirations within this field.

The incentive for Vinnova to finance the project was to further promote innovative procurement and draw lessons from the project on how procurement as a tool can foster innovation. Without the financial support from Vinnova, the project would not have materialised as the financing ensured that the necessary expertise and competencies could be brought into the project.

Even though the manufacturers showed interest in the project, the dialogue revealed that their incentives to develop a PVC-free blood bag were relatively low, due to the fact that the market was perceived as too small compared to the investments that would have to be put into the R\&D phase. Their incentive would have been stronger had there been a larger demand in sight. There has been no indication of trying to affect the European standards in order to get hospitals in other European countries to use PVC- free bags instead of the traditional ones. This could have helped to spur the process. Subsequently the learning point is:

- Showing demand is crucial in order to increase the manufacturers incentive to participate in an innovative procurement

- Without the financing from Vinnova the project would not have materialised. This case thereby demonstrated that there is a need for financing from national bodies.

\section{Risk management}

Dialogue with the manufacturers highlighted that one of the main risks from their point of view was that the market for PVC-free blood bags was not large enough or built quickly enough to justify capacity investment in the R\&D necessary to produce the bag. The manufacturers feared to be caught in the market failure trap, i.e. to have invested heavily in $R \& D$ without the scale to get the necessary return. The manufacturers thus pointed out that the motives of the purchaser group needed to be made clear. The purchaser group subsequently formulated a letter of intent, which was signed by a large group of county councils and regions. The purpose of the letter of intent was to give the manufacturers information about their intentions and thereby provide financial incitements and reduce risk. However, the manufacturers were still concerned that the Swedish market was not large enough. Subsequently the purchaser group tried to increase demand internationally by getting organisations in USA and Europe to sign a petition stating that they support the initiative to develop and diffuse a PVC-free blood bags. In total 40 representatives from different countries and organisations signed the petition. 
The financial risk was also an issue seen from the point of view of purchaser groups. In this case the financial risk was that the endproduct would be too expensive. The project manager highlights that if the project leads to procurement, one way to overcome the financial risk could be to include a clause in the tender stating that the end-product cannot be too expensive. Another way to deal with the financial issue would be a niche market approach whereby PVC-blood bags are procured for high risk patient groups only.

Project management is also highlighted as a potential risk. The blood bag project involved a number of councils and regions as well as experts and consultants. A set project management was required in order to bring together the different stakeholders and ensure the progress of the project. Hence, the key learning point is:

- In joint procurement involving a large number of public organisations a set project management is required in order to bring together the different stakeholders and ensure progress.

\section{Learning points}

This case has demonstrated a very thorough process relating to the feasibility study with a number of experts and a study on the opportunities in the legal framework. The case demonstrates the importance of involving the companies at an early stage and of creating a strong incentive through demand to ensure their involvement in the development process.

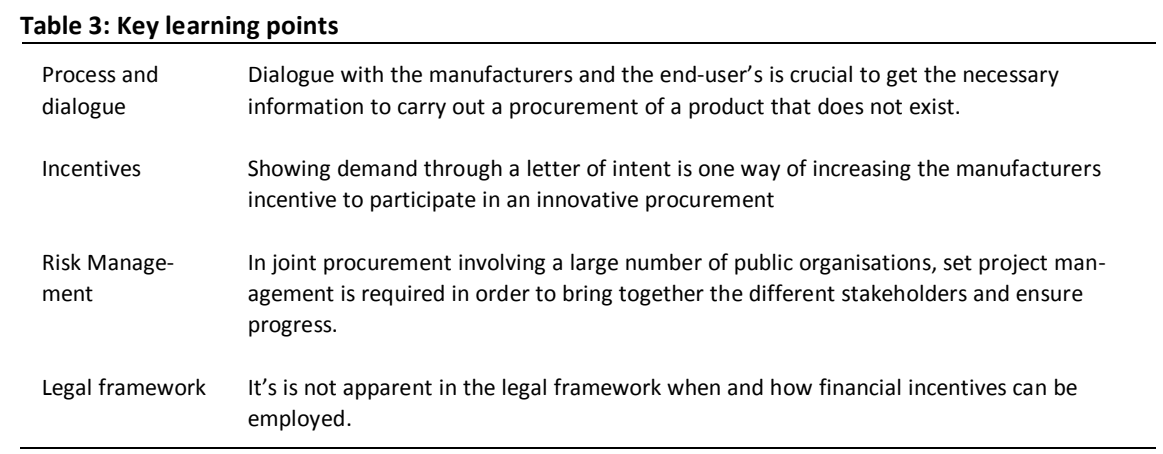




\subsection{Iceland: Core laboratory}

\section{Introduction}

The Core Laboratory concerns the reorganising and modernisation of a laboratory at the Department of Clinical Biochemistry at the University Hospital in Reykjavik (Landspitali). The point of departure for the process was that the clinical diagnostic equipment was old and with tremendously high repair costs. With a new line of equipment at the lab, Landspitali expected to gain increased productivity and thus lowering the costs which was the ambition for the innovative procurement process. This case is known as best practice because:

- It demonstrates a way to use innovative procurement with a predominant focus on increasing efficiency and hence adhering to an agenda demanding cost cutting

- It is one of the very first examples of innovative procurement in Iceland with the perception that it could be precedent for other similar cost cutting initiatives

The process was initiated with a dialogue session with companies. Companies not meeting the expectations and requirements from Landspitali were deselected from the process. The concept is that dialogue will continue until only two companies remain. The remaining companies will compete on the lowest price in order to be awarded the tender. The steps in the process are depicted below.

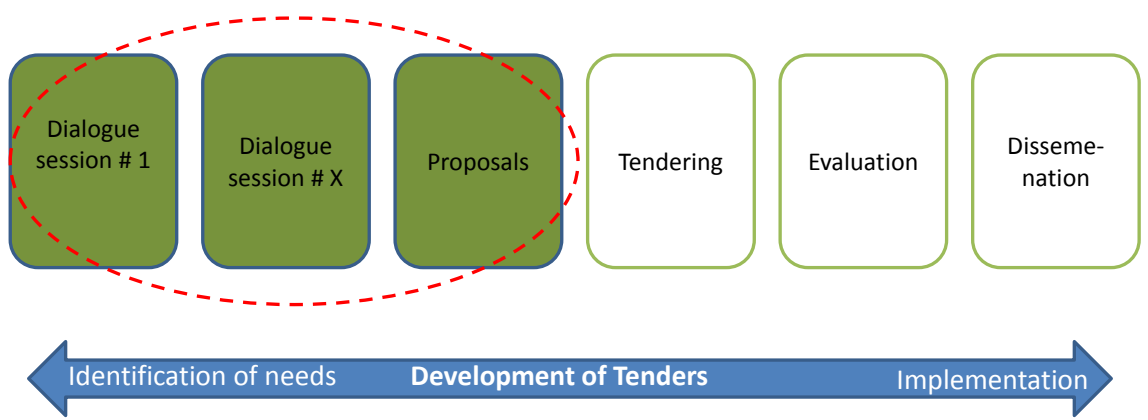

Figure 6: Procurement stages

Source: DAMVAD 2011

\section{Process and Dialogue}

The process was based on elements selected from competitive dialogue providing the overall frame for the procurement process. The public organisation established contact with the companies by announcing the invitation to participate in a dialogue conference regarding the arrangement of the Core Lab through the homepage of the State Trading 
Centre, Rikiskaup, where all procurement announcements within health care are announced.

An advisory group consisting of doctors, laboratory technicians, clinical engineers, scientists, lawyers with expert knowledge in the clinical, technical and legal field related to the tender will assess the proposals.

Based on the first round of dialogue, the first group of companies will get deselected. The dialogue process is continued until the optimal balance between price and quality is found in a tender. The job will be awarded to the company demonstrating the most economically advantageous tender. The process is still in progress, however initial key learning points relate to:

- Even though Landspitali could collect knowledge on how other hospitals arranges their laboratories and copy their practice, a process with dialogue ensures that new inputs from the market is included and may provide solutions not even available in other laboratories.

- With complex procurement such as a laboratory's interior design and functionality, it has proven to be a positive approach to use competitive dialogue despite the use of additional resources.

\section{Legal framework}

From the point of departure and throughout the process, there has been close collaboration between the procurement unit at Landspitali and procurement experts at Rikiskaup, in relation to considerations on how to work with the legal framework.

The assistance from Rikiskaup has been useful to the legal design of the process and to give their endorsement to the choice of the process. The legal guidance has enabled Landspitali to focus the majority of its resources on the content of the laboratory and the dialogue, as Rikiskaup has dealt with the legal twists. Hence, learning points relate to:

- The collaboration with Rikiskaup has been central to navigating the legal framework especially since innovative procurement is not that common in Iceland and with few cases to rely on.

\section{Incentives}

The incentives for Landspitali to embark on a new and more complex procurement method than traditional procurements were compiled in the overall belief that a process allowing for dialogue with the market would result in a better solution for the lab. Moreover, there was a strong incentive in making operations more efficient than what the current laboratory could facilitate and the expectation was that modern technologies could assist in achieving this ambition. The aspiration to get more familiar with the innovative procurement process served as a motivational force for Landspitali and Rikiskaup as the purchasers.

The main incentive of the participating companies is related to the possibility of supplying the hospital with a new solution thus resulting in 
the sale of the companies' services. As the process was structured with continuous eliminations, it gave participating companies a direct incentive to keep providing good inputs to the solution, as the risks of not continuing in the run of getting the award for the contract were always present.

Key learning points relate to:

- The incentive for Landspitali and Rikiskaup relating to a new kind of laboratory and to gain experience with innovative procurement has been a strong force enabling the additional costs of completing such a process.

- The concept of continuous eliminations served as a motivational aspect for the companies. However, it appeared that the selection criteria were not as transparent as the companies could have wished for and this compromised the incentives to participate.

\section{Risk management}

As part of the initial considerations of the procurement process financial risks were identified as the overriding risk of the procurement process. Hence as a way to proactively deal with this risk, the total estimated cost for the project was announced in the beginning of the process.

By using competitive dialogue, Landspitali has experienced that they were diminishing the kind of risks that are associated with failing to identifying different needs. The inclusion of companies through dialogue and the advisory group with a broad representation of the potential users have contributed to a set up that helps reduce risks of purchasing a solution that does not meet the needs and expectations of the daily users.

The experience from the process has also encompassed that the inclusion of different companies in a dialogue phase with continuous eliminations of companies increases the risk of complains sent to the Competition authorities. Landspitali and Rikiskaup already got two complaints from the same supplier with acquisitions of unfair competition. Hence, key learning points refer to:

- The risks of procuring a solution not meeting the needs of users have been eliminated by having an advisory group consisting of potential users as part of the process.

- It was attempted to deal with the risks of having several companies as part of the process up front through considerations on the design of the process, however, it has not been possible to eliminate the risks of complaints.

- The complaints underline the risks associated with the introduction of a new approach to procurement deviating from standard procurement.

\section{Learning points}

This case has demonstrated that innovative procurement can be initiated from a need to increase efficiency and with cost cutting as the overall goal. Despite the acknowledgement that there are increased costs 
associated with a more prolonged process, it is in this case the intention that the overall results from the comprehensive process will result in a solution that exceeds the costs. There are insecurities relating to the application of new procurement processes; however the legal assistance from an institution such as Rikiskaup has helped to eliminate the uncertain elements. As the process is not terminated, it remains to be seen how the final results of the innovative procurement process ends. The conclusions from the case are summarised below.

Table 4: Key learning points

$\begin{aligned} & \text { Process and dia- } \\ & \text { logue }\end{aligned}$
$\begin{aligned} & \text { Competitive dialogue was used as the overall approach to the process enabling the } \\ & \text { inputs from companies into the solutions to the design of laboratory. }\end{aligned}$
$\begin{aligned} & \text { The main incentive was a more efficient laboratory including the newest technological } \\ & \text { solutions and to gain experience in using innovative procurement. Companies' incentives } \\ & \text { were the outlook of winning the contract with the commercial perspective. }\end{aligned}$
Risk Management $\quad \begin{aligned} & \text { Financial risks were reduced by announcing total costs of the project. A new procure- } \\ & \text { ment method increases the risk of getting legal complaints from companies. }\end{aligned}$
Legal framework $\quad \begin{aligned} & \text { The inclusion of Rikiskaup as part of the procurement process has ensured that the } \\ & \text { process was in line with the legal framework by assisting with their legal experience in } \\ & \text { the design of the process. }\end{aligned}$




\subsection{Sweden: Meal Services for the Elderly}

\section{Introduction}

In 2008, Swedish municipalities and county councils spent 9 billion SEK (excluding VAT) on publicly served meals for the elderly. Still, the meal services do not cater for the needs of all elderly people. As a consequence, a number of elderly suffer from malnutrition, which leads to increased health care costs. Both procurers and suppliers believe that one way to improve the meal services is through public procurement process. On this basis, a project was launched by Region Skåne and Skåne Food Innovation Network to look into the possibilities and barriers associated with implementing innovative procurement of meal services for elderly. This case is known as best practice because:

- It is the first example of a new and well-structured approach to innovative procurement that has been launched in Region Skåne. 6 The approach includes starting from a specific problem and thoroughly investigates the origins of the problem in order to come up with a solution.

As outlined in the figure below, the project included a feasibility study, dialogue with procurers and staff members working with elderly people and an outline of how a municipality could go about an innovative procurement of meal service for the elderly. The project was financed through Vinnova's Innovative Procurement Programme.

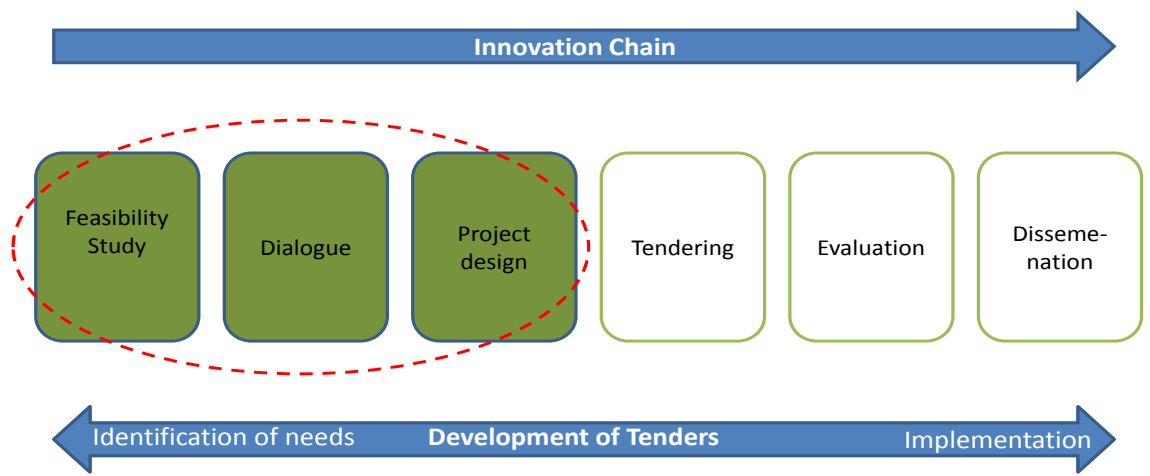

Figure 7: Procurement stages

Source: DAMVAD 2011

${ }^{6}$ The overall concept also includes an idea bank for innovative ideas deriving from hospital staff and companies. The most promising ideas are selected to undergo a feasibility study. Those ideas demonstrating a market potential will be launched through an innovative procurement process with the region as the guaranteed first customer. More ideas are currently in the loop to start the process. 


\section{Process and dialogue}

The purpose of the feasibility study was to undercover the needs of the elderly. In order to do so a case study was undertaken. The municipality of Kävlinge was chosen as the case study object and a number of interviews with different people working with elderly and nutrition were completed. The study also included a review of how procurement of meal service for the elderly is currently carried out in Kävlinge.

The case study resulted in a number of recommendations on how to develop meal services through innovative procurement as well as an outline on how a municipality could go about doing an innovative procurement of meal services for the elderly. This includes an outline of a requirement specification as well as a description of possible procurement approaches which could be used. Contrary to existing requirement specification it is a very open approach. For instance instead of specifying the nutritional content in the meals that are to be delivered, it is specified that "There is a need for a meal solution that meets the needs of the elderly in terms of energy and nutrition. The meal solution should contain six meals, divided into three main meals and three snacks".

The feasibility study did not include contact with potential suppliers. It was supposed to be followed by a procurement phase. However, the study uncovered that it would be difficult for one municipality to carry out innovative procurement of meal service for elderly since it would most likely be associated with additional costs to encourage involvement and risk taking of potential suppliers. Even if more municipalities collaborated, there would still be a need for a coordinating body as well as financing to cover the additional costs related to the procurement. Since the financing from Vinnova only covered the feasibility study, the project has been halted. However, the lessons learned are to be carried on in a new project about secondary prevention through meals. The project is co-funded by Vinnova and the Region Skåne, as part of Region Skåne's ambition to become the food region of the northern Europe as well as their ambition to promote innovation through public procurement.

Key learning points refer to:

- Innovative procurement entails additional costs that can be hard for one municipality or region to cover

- Thorough investigation of the end-users' need ensures direction in the procurement

- An open requirement specification is one way to provide suppliers with the necessary incentive to come up with new solutions.

\section{Incentives}

The main incentive for the region was the need to address a current problem of an increasing amount of elderly suffering from malnutrition during their last years. The region thus wanted to look at how to structure meal services in order to solve the problem of malnutrition. 
Furthermore, procuring a new type of meal services was seen as an opportunity to test the procurement approach as a tool to promote innovation. This incentive was further strengthened through an inquiry from Vinnova to Region Skåne. Vinnova was trying to launch their programme within Innovative Procurement and saw potentials in supporting the initiatives from the region.

The feasibility study did not include an investigation of the companies' incentives to take part in developing the meal service for elderly. Hence, a key learning point refers to:

- An important issue in the preparatory phase of an innovative procurement is finding incentives encouraging suppliers to get involved in the development process.

\section{Legal framework}

The working group approached the issue of innovative procurement of meals for the elderly from an organizational and economic angle, rather than a strictly legal. It was never the intention to do a thorough investigation of the legal framework. Nevertheless, one of the results from the project was that the legal framework discourages small businesses from bidding especially when high demands related to the company's financial situation is made. This in turn leads to market competition being inhibited and thus new concepts and ideas are potentially not brought to the table.

Even though the particular case did not investigate the possibilities and barriers in the legal framework, determining the possibilities that lie within the legal framework is part of the Region Skåne's initiative to develop procurement as a tool of promoting innovation. It is highlighted that an innovative procurement of meal service for the elderly should be carried out in close cooperation with legal experts.

A key learning point is:

- In order to encourage small businesses to participate in innovative procurement processes demands related to the company's financial situation ought to be taken into consideration.

\section{Risk management}

An investigation of risks associated with an innovative procurement of meal services was not included in the first phase of the project. However, it is possible to identify some of the potential risks that could emerge during an innovative procurement process of meals services. One such risk is related to the internal organisation of the procurement process. Originally, Region Skåne was intended to be the contracting authority in the actual procurement process and act as the first customer. However, during the feasibility study it was uncovered that the municipalities were the actual procuring agents giving that the problem with malnutrition started in the home, not at the hospital. Furthermore it's the municipalities that do most of the procuring within this area. The focus 
therefore shifted from a regional to the municipality level. However, Region Skåne still remained part of the project.

Another risk is related to the market. The current meal service market in Sweden is dominated by larger companies. One of the purposes of doing innovative procurement of meal services would be to expand the number of suppliers which would hopefully lead to new ideas and concepts being introduced. Strict requirements related to the financial performance of the companies could however lead to the exclusion of smaller companies. One of the ways to minimise this risk would be to actively include suppliers of different sizes when working together with suppliers to come up with new meal service solutions. Hence, a key learning point is:

- Competition can be distorted and innovation inhibited if the procurement process is not designed in a way that includes small as well as larger businesses.

\section{Learning points}

This case is an example of a new and well-structured approach to innovative procurement launched in Region Skåne, which includes starting from a specific problem and thoroughly investigating the end-users needs. This ensured that the requirement specification was in line with the end-users' need.

Further learning points are summarized in the table below.

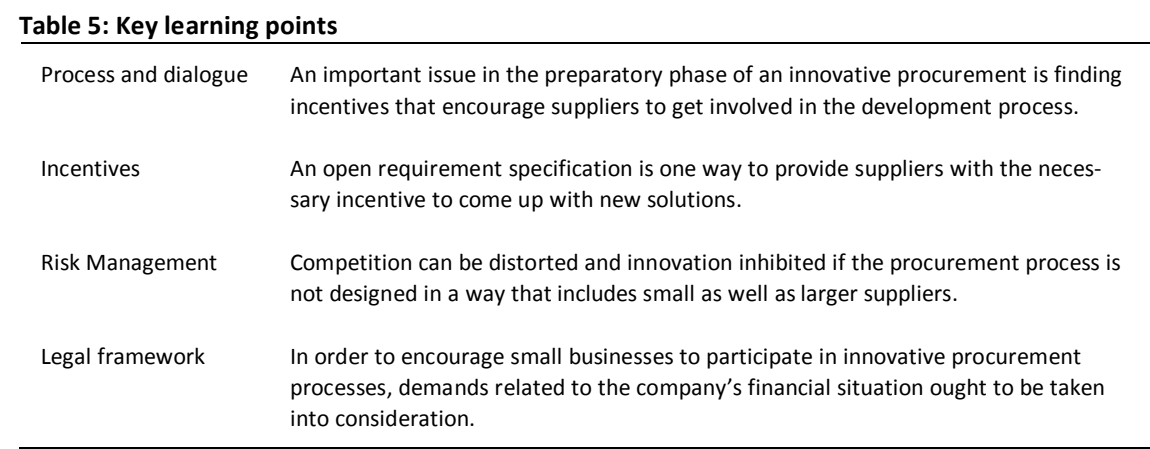




\subsection{Finland: Supported Housing Services}

\section{Introduction}

A desire to heighten the quality in supported housing services and expand the market served as the starting point for municipality of Vantaa to look at their procurement process. An innovative procurement process was thus launched with the objective to procure a new type of customer-oriented service concept as well as creating a functional market for supported housing for the severely disabled.

This case is known as best practice because:

- It is one of the few Scandinavian examples of innovative procurement which has been completed.

- Thorough dialogue with end-users and service providers was carried out. The dialogue led to an improved requirement specification which in terms led to an improved service level.

The overall approach to the procurement process has been to use dialogue with the private providers of supported housing services and the end-users (the severely disabled). Following the dialogue, a requirement specification was formulated and potential service providers were invited to negotiations. Based on the negotiations the service providers handed in their offers. These were evaluated and contracts were signed with nine suppliers. The stages are summarised in the figure below.

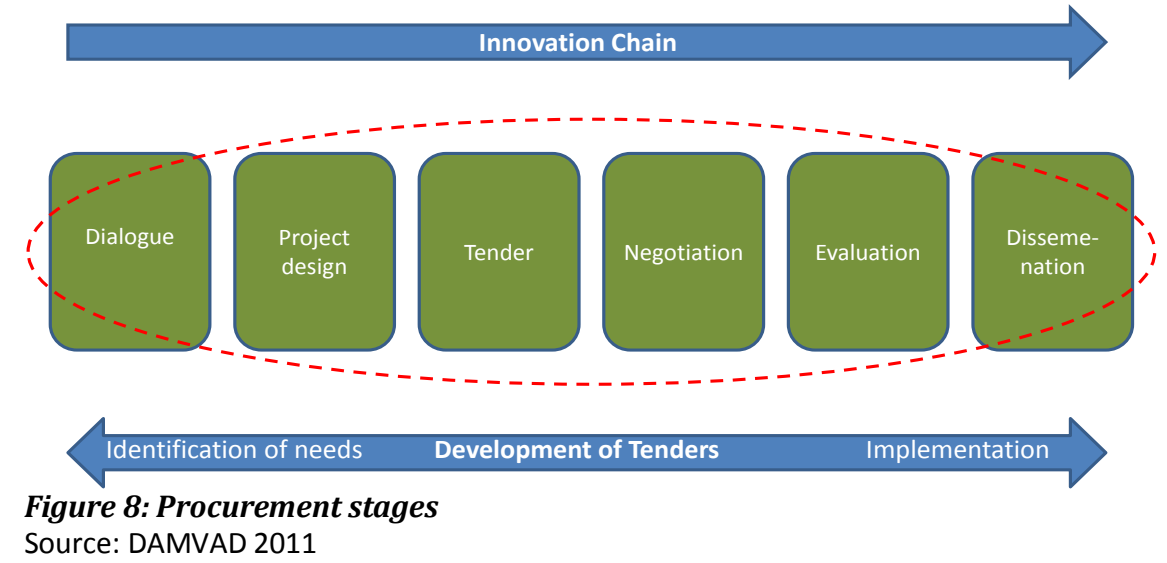

\section{Incentives}

The main incentive for the public procurement unit at the municipality of Vantaa was to procure high quality supported housing services. Additionally, the motivation was to increase the quality of the services provided without increasing the price. The main incentive relating to the choice of an innovative procurement process was the possibility of engaging in dialogue with providers as well as the end-users. Conducting an innovative procurement was made possible through funding from the Finnish national innovation agency, Tekes. Tekes funded 50 per cent of 
the total expenses through their national funding programme for Innovative Procurement. Had it not been for the funding received, the procurement unit would have proceeded with ordinary procurement.

The service providers had diverting incentives. The incentive to engage in dialogue for the service providers that previously had had contracts with the municipality was the opportunity to maintain their market share by getting a better understanding of the type of services that the municipality was looking for. For new service providers the dialogue and negotiation gave them the opportunity to enter the market.

Key learning points are:

- The funding from Tekes served as an incentive for the municipality to carry out an innovative procurement instead of an ordinary procurement.

- The possibility to engage in dialogue and thereby get insight into each other's needs served as a clear incentive for both the public and private parties.

\section{Process and Dialogue}

The procurement was carried out by a working group consisting of procurers and specialists within the field of supported housing for the disabled from the municipality of Vantaa. It took approximately 8 months from the start of the process to the signing of the contracts.

The fundamental principle behind the procurement process was engaging in dialogue with providers and end-users. In order to do so, a survey was conducted among disabled already living in supported housing as well as disabled living in their own homes by a university of applied science. The purpose of the survey was to get insights into how the current services could be improved to ensure that the services procured would satisfy the end-users' needs. Some of the suggestions made in the survey were included in the requirement specification. For instance it was specified in the tender that the private providers of supported housing services to the extent possible should ensure that the disabled lives with people in the same age group.

Following the dialogue with the end-users, the procurement unit engaged in dialogue with services providers. The procurement unit contacted selected local service providers directly and invited them to engage in dialogue. The process was organized with the help of a professional facilitator. In-house specialists in supported housing service also participated in the dialogue.

The dialogue with the service providers led to a number of improvements to the actual tender process. For instance based on the dialogue, it was allowed for small service providers to team up to hire the necessary specialists such as physiotherapist. This meant that smaller service providers that would have otherwise been excluded were able to bid. In the end this meant that the number of providers awarded a contract was expanded from five to nine. 
Next step in the procurement process was tendering and negotiations with the suppliers. Nine local service providers responded to the public tender and were invited to a negotiation, where the content and quality of the services were discussed. Based on experiences from other innovative procurement projects obtained through a seminar held as part of the project, the manager from the social and health department who had the final say in who would be awarded a contract, participated in the negotiations. This made the evaluation phase less time consuming.

Following the negotiations the providers handed in their offer. The incoming offers were evaluated and contracts were made with nine private service providers.

Key learning points are:

- Having a professional facilitator and specialists with in-depth knowledge about the service working alongside procurers ensured a constructive dialogue with the suppliers.

- Dialogue with service providers and end-users led to significant improvement in the tendering processes thus leading to increased quality in the procured services.

- Having the final decision maker involved in the negotiation made the evaluation process less time-consuming.

\section{Legal framework}

Dialogue is not commonly used in procurement in the municipality. Due to a strict interpretation of the legal framework and a fear to do something that falls outside the legal boundaries, dialogue has often been avoided. Subsequently, one of the main issues that had to be dealt with was the legal issues relating to dialogue and negotiations with service providers. In order to provide the procurers with the necessary knowledge, two seminars on legal issues related to innovative procurement was held. The seminars were conducted by an expert in the legal issues associated with innovative procurement and ensured that the procurement process was in line with the legal framework. One of the main lessons was that it is possible to carry out dialogue as part of the procurement. The funding from Tekes made it possible for the municipality to acquire the necessary counselling. Key learning points are:

- The legal framework does not exclude dialogue even though it does impose some restrictions.

- Bringing in a legal expert gave the procurers the knowledge necessary to engage in dialogue with the service providers.

\section{Risk management}

One of the main risks related to the procurement was related to interpretation of the legal framework. Since dialogue was only carried out with a selection of the service providers, there was a risk of competition being distorted, which could lead to service providers being excluded. 
The seminars held by the legal expert were crucial in order to eliminate the risks associated with dialogue. To overcome the risk of exclusion, all communication and information related to the dialogue was offered to all the service providers at the beginning of the tendering process.

Another risk identified in the procurement process is related to the internal organisation. The working group that carried out the procurement consisted of procurers as well as specialists in support housing services. Changes in personnel during the procurement process led to a delay in the process.

Key learning points are:

- Legal counselling and support ensured that the procurement process was in line with the legal framework and thereby reducing risks.

- All communication and information given to service providers during the dialogue process were open to all bidders to avoid the risks of exclusion.

\section{Key learning points}

In the procurement of supported housing services continuous dialogue with service providers and end-users proved crucial to improving the quality of the services and expand the market of service providers. The procurement unit had little experience with including dialogue and negotiation in the procurement process and legal counselling and support ensured that the procurement process was in line with the legal framework.

Further learning points are summarised in the table below.

Table 6: Key learning points

$\begin{aligned} & \text { Process and } \\ & \text { dialogue }\end{aligned}$
$\begin{aligned} & \text { Having specialists with in-depth knowledge about the product or services working } \\ & \text { alongside procurers ensured a constructive dialogue with the suppliers. }\end{aligned}$
$\begin{aligned} & \text { The possibility to engage in dialogue and thereby get insight into each other's needs } \\ & \text { served as a clear incentive for both the public and private parties. }\end{aligned}$
Risk Management $\quad \begin{aligned} & \text { Legal counselling and support ensured that the procurement process was in line with } \\ & \text { the legal framework thereby reducing risk }\end{aligned}$
Legal framework $\quad \begin{aligned} & \text { The legal framework does not excluded dialogue with providers even though it does } \\ & \text { impose some restrictions. }\end{aligned}$




\subsection{Norway: Care +}

\section{Introduction}

A better and richer life for the elderly living at lifetime care houses was the point of departure for Oslo Municipality when engaging in dialogue with suppliers and other companies regarding the construction of up to 1000 new lifetime care houses with the use of welfare- and smart-house technologies. This case is known as best practice because:

- The municipality used its lack of market knowledge to initiate a process where dialogue with companies was central.

- It demonstrates how the inclusion of legal guidance from government authorities help reduce insecurities relating to the application of new procurement methods

- The project has a significant volume ensuring a prominent base for generations of experiences applicable to other municipalities in Norway

The overall approach to the procurement process in Care + has been to use dialogue with the market to design a functional and user-driven requirement specification for the lifetime care houses. The process is still a work in progress and has currently finalised the specification requirement thus enabling the tendering process at the nearest future. The stages are summarised below.

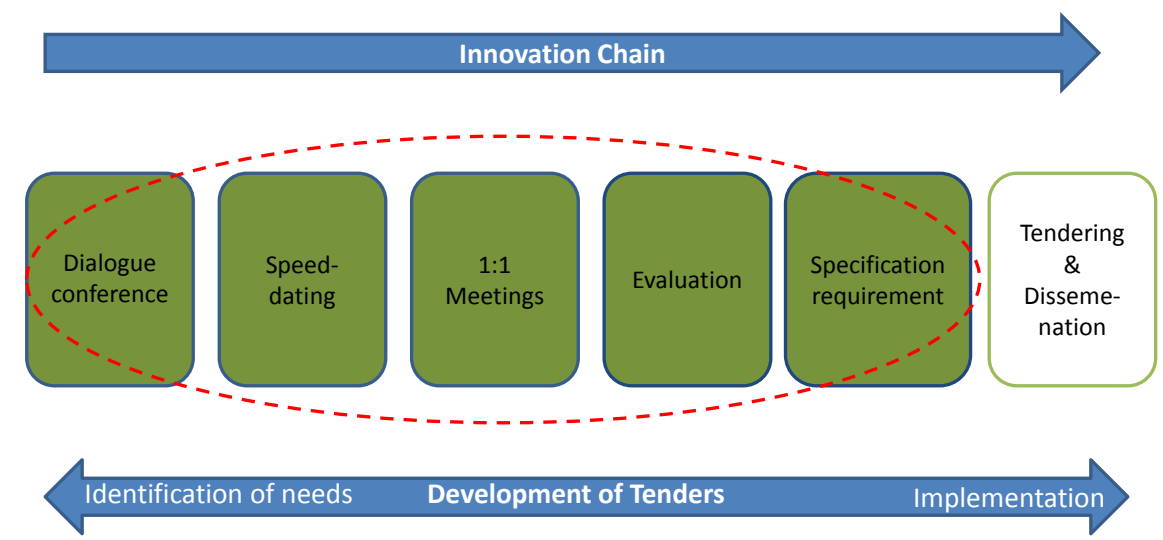

Figure 9: Procurement stages

Source: DAMVAD 2011

\section{Process and Dialogue}

The procurement process was initiated with a dialogue conference. The municipality established contact to the companies through Doffin (The Norwegian national database for public procurement) where the invitation to participate at the conference and the purpose hereof was announced. This ensured that all interested companies could participate. In the announcement, the municipality underlined their interest in complete solutions considering the interplay of technologies. The interest of 
the companies in participating far exceeded the expectations of the municipality.

Next step included a speed-dating session where companies could present themselves and partner up to combine their competences in the proposals to the municipality. This part was facilitated by the cluster organisation, Oslo Medtech which helped ensure a neutral meeting point.

Subsequently, the companies submitted their proposals to Oslo municipality. The municipality received 30 written proposals where several were from consortia of companies. The proposals contained a range of different solutions and the suppliers behind them originated from a broad geographical area in Norway representing different industries and both small and large companies. An interdisciplinary evaluation group from the municipality evaluated the proposals, which resulted in the development of the specification requirements that were to be central in the tendering phase. Before the specification requirements were announced, relevant interest groups commented on the draft. The specification requirements will be announced in Doffin at the beginning of 2012. Key learning points relate to:

- Dialogue as part of the process was beneficial in order to address the knowledge gap that the municipalities as relatively small procurement units face in Norway

- Speed-dating as a way to facilitate knowledge exchange and partnering possibilities was useful and an approach that is recommended for future innovative procurement.

- The use of Doffin was a useful tool in ensuring transparency and openness for all interested companies

\section{Legal framework}

The legal framework and the opportunities for innovative procurement were considered from the initial phases in the process. The main considerations concerned the inclusion of dialogue with companies as part of the process. As the participating companies have primarily contributed with their knowledge of existing technologies and their applicability, it is not prevented in the existing legal framework.

The Supplier Programme has been part of the entire process by providing legal counselling and guidance relating to the different legal opportunities and their consequences.

Generally, it was the perception that the legal framework did not pose any restrictions to the process. However, it did require a lot of knowledge regarding the legal framework and its limitations which most likely could not have been achieved without the assistance from the Supplier Programme. Thus key learning points refer to:

- The affiliation of the Supplier Programme has been a key to the success. The legal competences have helped eliminate the insecurities related to the use of a different procurement process. 
- The guidance from the Supplier Programme has ensured that dialogue became a significant part of the process.

\section{Incentives}

The main incentive for the public procurement unit at the municipality is to find a solution to the design and arrangement of lifetime care houses that can help the users to become more self-reliant and increase their quality of life. Additionally, the use of technologies that can help release time from health care staff to do other duties closer to the patients' needs has served as incentives.

The main incentive for the companies to participate in an innovative procurement process relates to the ability of generating sales to the municipality. Because the scale in this project is quite significant, there is a substantial commercial perspective for the companies. This incentive has been the driver for their participation and effort in affecting the way the specifications in the final tender are made. However, the companies are not guaranteed sale as part of the process.

The participating companies also consider it a benefit to the process that they have gained a better understanding of the reality in procurement units. It is the perception that it will assist them in all future procurement in the health sector.

Key learning points refer to:

- Dialogue with companies help increase the level of market knowledge for the municipality. However, the inclusion of dialogue also makes the process more complex as it results in an overflow of information that needs to be processed.

- The companies are motivated to participate in the process due to the outlook of a large scale sale. However, the process has not ensured real commercial incentives for the companies that to some extent contribute with their resources without knowing if they will get commercially rewarded.

\section{Risk management}

The main risk associated with the project was considered to be the lack of market knowledge. This was addressed with the process relying on dialogue. The risks relating to the inclusion of dialogue was dealt with through counselling from the Supplier Programme.

It is the expectation that as soon as the next phases of the procurement process starts, financial risks may evolve as a challenge that needs to be addressed. Finding the right language in the specification requirements with the ability to enable the best suppliers to participate while not excluding others has been another key risk in the process. In relation to this a future risk is associated with the selection of the best suppliers for the lifetime care houses. Hence, key learning points are: 
- The thorough process resting on dialogue has made the procurement unit at Oslo Municipality more confident in their knowledge of the market thus making it easier to define the right selection criteria and reduce the risk of excluding prominent contributions

- The continuous dialogue with relevant stakeholders and in particular the guidance of the Supplier Programme is seen as a way to act proactively on potential risks

- All communication and information regarding the procurement have been open to all to avoid the risks of exclusion and legal complaints on this background.

\section{Learning points}

The key learning point of this case is the importance of having legal support and counselling as part of the process to help endorse the decisions relating to the interpretations of the legal framework. The benefits of using dialogue as a way to include knowledge from the companies have been crucial. Providing real commercial incentives for the participating companies may provide a future focus area.

A reflection for next practice within innovative procurement in Norway is the inclusion of SMEs in the innovative processes within health care. Hospitals have a preference for cooperating with large companies in procurement issues because of their security of supply. There is a strong orientation, also from the hospitals, to include SMEs in innovation works among other things through incubator functions at hospitals.

Further key learning points are summarised in the table below.

\begin{tabular}{|c|c|}
\hline $\begin{array}{l}\text { Process and dia- } \\
\text { logue }\end{array}$ & $\begin{array}{l}\text { Dialogue with suppliers has been a central dimension in the process adding to increase } \\
\text { the level of knowledge when developing the specification requirements. }\end{array}$ \\
\hline Incentives & $\begin{array}{l}\text { Relate to acquire better homes for the elderly with the newest technology assisting the } \\
\text { elderly in becoming more self-reliant. Because of the large scales in the project, there is } \\
\text { a commercial incentive for participating companies. }\end{array}$ \\
\hline Risk Management & $\begin{array}{l}\text { There has been no direct approach to risks, however, they have been considered and } \\
\text { dealt with as they emerge. There are currently considerations to future risks related to } \\
\text { the continuation of the process. }\end{array}$ \\
\hline Legal framework & $\begin{array}{l}\text { The assistance from the legal experts related to the suppliers' programme has been very } \\
\text { valuable for the process. Their endorsement of the choice of procurement method and } \\
\text { process has helped reduce the uncertainties related to the innovative procurement } \\
\text { process. }\end{array}$ \\
\hline
\end{tabular}




\section{From Best Practice to Next Practice}

This section presents the learning points that have emerged across the six different Nordic cases within innovative procurement in the health sector. As the cases are different and embedded in different legal systems, there will be differences in the levels of learning and applicability across the five countries. The following table present the key learning points derived from the cases.

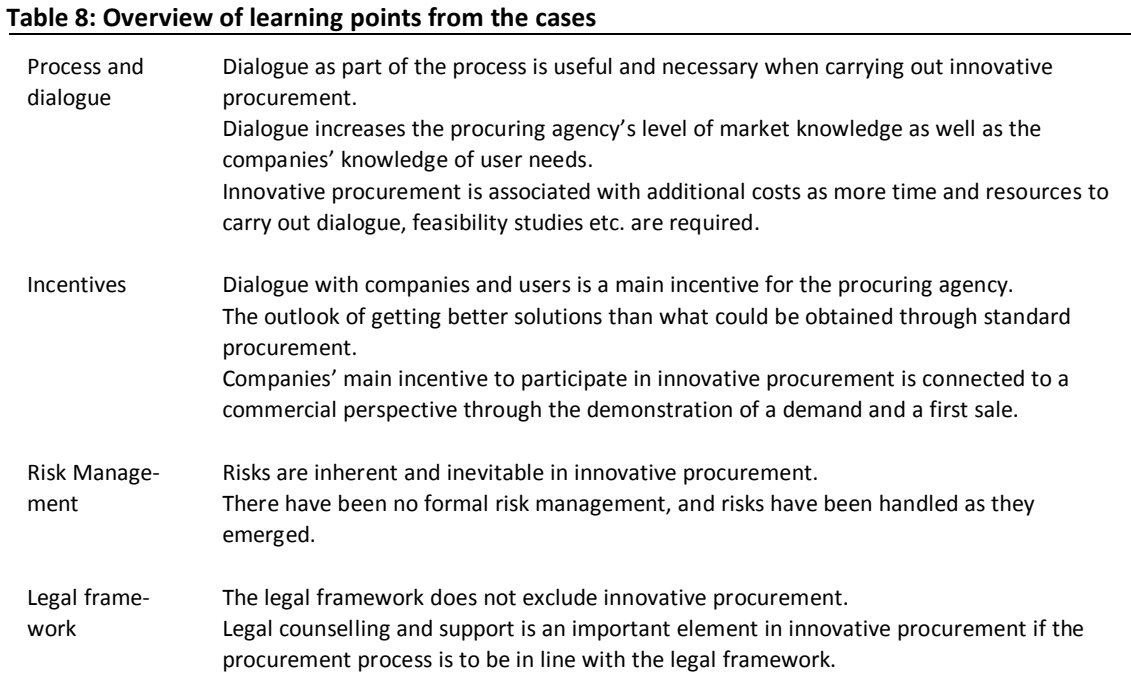

The following presents key insights from the study which also demonstrating insights into what determines next practice.

\section{Complicated, but not opposing legal framework}

All the cases demonstrate that it is a challenge to navigate within the legal framework of procurement. It is acknowledged that the legal framework in itself does not prevent or oppose procurement of innovation and innovative procurement processes, but the legal framework does not enhance it either. Furthermore, the rules and regulations connected to procurement are complex and require a great amount of legal competences involved in the process in order to ensure that the law is not broken. The ability to deal with the legal challenges has differed across the cases because of the different interpretations of the legal framework on national level and the ability to provide legal guidance.

In particular, the Danish case on the hospital bed has illuminated how the government authorities have not been able to give their endorse- 
ments to the choice of procurement method leaving the handling of legal risks and the related financial costs to the initiating region alone. The Norwegian case however has demonstrated that government authorities without compromising the procurement laws can assist in and guide the interpretation of the legal framework. Hence, across the Nordic countries there are different models as to how the innovative procurement is supported by the government authorities.

There is a request for tools assisting the guidance on the classic legal pitfalls and how to solve them presented in a straightforward and practice oriented language. In this relation, practitioners note the relevance of having examples on how other practitioners have dealt with these issues. The cases presented in this report to some extent represent pioneers within their field and their experiences should be shared with others in order to raise the bar. Because of the different levels of the assistance, there may be different needs to address across the Nordic countries.

\section{Incentives for innovative procurement, but also increased costs}

Across the cases, it can be gathered that there are incentives to embark on innovative procurement. Because of the extended processes, innovative procurement entails additional costs. For the public purchasers these costs relate to the time and resources spend on organising and implementing the prolonged processes. As indicated, the public procurers consider it a necessary investment in order to perform more innovative processes and achieve better results through a more thorough process including the crucial inputs from the market and the end-users.

For the companies participating in the innovative procurement process, the investments in the process may result in sunken costs as the commercial results may not always be guaranteed. Based on the interviews with company representatives, there is a clear indication that the companies consider it worthwhile to participate in the extended procurement process, however with differing degrees to this interest. It has been argued from companies participating in dialogue conferences that their time and resources spend may be in vain as it is not certain how the commercial outcome is. Additionally, it is not a common practice to pay companies for their contributions to the process which could provide a clear incentive to participate. The case of Care + has revealed considerations from participating companies relating to a fear of the result of a process where small and innovative Norwegian companies have participated in the dialogue process with the municipality and invested their time and resources to assist the process, only to realise that the specification requirements are so broadly defined that all global companies can make a bid.

It was noted from the cases that companies' incentive increase when there is a guarantee of a first sale provided by the public institution or when companies were compensated financially to participate in long innovative processes. 


\section{Risks are a part of innovation}

Concerning risks in the innovative procurement process, the case participants were very unanimous in their responses, stating that risks are inherent and inevitable when talking about innovation. Innovation put in relation to procurement processes just add to the risks. The cases have demonstrated different, but overall successful approaches to risks.

All cases had initial considerations as to which risks were likely to emerge and what could be done to prevent them upfront. When the public sector acts as the first buyer, it helps shrink the companies' risk when engaging in a long development process with associated costs without benefitting for their effort. If the risks of getting involved in a joint development process are too great, no companies will see the benefits in participating. Additionally, the risk of legal incapacity for the companies, due to joint development projects with the public institution, is critical to companies' participation in innovative processes with a public player. This can be handled by the way procurement is arranged. In the Danish case these risks were handled by the way the tender was composed by directly describing that the region would purchase the developed bed once the innovation and development phase was terminated. Risks from the public institutions related to their prevention from purchasing inventions they have participated in developing, are also addressed when the actual purchase of units is included in the tender from the beginning.

The issue of risk management is a focal point to all innovative procurement types in health care. The practitioners call for instruments that would help reduce the risks of innovative procurements for both the public and private side for instance by developing models for sharing of risks. Currently, it is up to the parties if sharing of risks and risk management are included at all.

\section{Dialogue is central}

All the cases have demonstrated that the use of dialogue is central to the innovative procurement process. Dialogue enables the parties to interact and share knowledge which is not an option in more traditional procurement types. The cases have shown different applications of dialogue ranging from dialogue meetings as part of the initial procurement phases where companies could provide inputs to the specifications in the tender to a more comprehensive use where dialogue processes were used to select the final tender. The practitioners noted that there had been uncertainties relating to the extent to which dialogue could be included in the process and suggested that experiences in this regard was collected across leading practitioners.

\section{Different procurement models for different needs}

The cases have demonstrated that different procurement models are applied. The procurement practitioners that have embarked on innovative procurements soon realise that there are several approaches to the design of an innovative procurement process. The final choice of the 
procurement model relies on the actual need that is supposed to be solved through the procurement. A key consideration relating to the choice of procurement method concern how companies are identified and through which channels the invitation to participate is announced.

The majority of cases have demonstrated that the public organisations use the traditional public procurement channels to announce the tenders hence ensuring open participation from companies. It is seen that the national databases and homepages are applied to get in contact with the companies. The Danish case additionally had announced the tender through EU.

It is however underlined that it can be difficult to make that choice on procurement model as there is so little experience to rely on and the consequences of choosing the wrong model are unknown. As it gets more common to conduct innovative procurement, there will be greater knowledge on the possibilities in each procurement method and hence when to use which procurement method. This will be a benefit for future practices.

\section{Different types of political measures}

The insights from the cases and the research conducted in relation to this study have indicated that there are different types of political measures that support innovative procurement. The table below highlights those measures identified in relation to the study.

\begin{tabular}{|c|c|}
\hline Political measure & Examples \\
\hline Funding & $\begin{array}{l}\text { Tekes (Finland) provide external funding to companies and procure- } \\
\text { ment units to carry out innovative procurement. } \\
\text { Vinnova (Sweden) provides funding for innovative procurement } \\
\text { including pre-commercial procurement } \\
\text { Region Skåne (Sweden) provides funding for innovative procurement } \\
\text { within the region. } \\
\text { The Business Innovation Fund (Denmark) has focused some of its } \\
\text { funds on financial support to procurement of pre-commercial solu- } \\
\text { tions. The fund supports the initial phases of procurement to do } \\
\text { studies on the potentials. } \\
\text { Rannis, Landspitali, Confederation of Icelandic Industries (Iceland) } \\
\text { support a process of public procurement for innovation where a } \\
\text { support fund would stimulate the process by funding of the procure- } \\
\text { ment. There is no experience gained yet }\end{array}$ \\
\hline $\begin{array}{l}\text { Upgrading of skills, network, } \\
\text { supporting facilities and legal } \\
\text { counselling }\end{array}$ & $\begin{array}{l}\text { The Supplier Programme (Norway) provides legal guidance to the } \\
\text { process, education and upgrading of skills of procurement officers and } \\
\text { overall information and guidance. } \\
\text { Rikiskaup (Iceland) provides legal guidance as part of overall assistance } \\
\text { to procurement } \\
\text { Danish regions may support innovation projects through public-private } \\
\text { collaboration that result in innovative procurement } \\
\text { Tekes, Vinnova and Region Skåne provide assistance to upgrading of } \\
\text { skills etc. } \\
\text { The Swedish Association of Local Authorities and Regions (Sweden) } \\
\text { runs a network on innovative procurement. }\end{array}$ \\
\hline Contracting & $\begin{array}{l}\text { Innovation Norway provides financial support through research \& } \\
\text { development contracts (IFU/OFU) to innovation projects in collabora- } \\
\text { tion between the public and private sector. }\end{array}$ \\
\hline
\end{tabular}


As the table shows, it varies across the Nordic countries which political measures that are available to procurement practitioners. It further demonstrates that the political measures support different stages and elements connected to innovative procurement ranging from financial support to conducting feasibility studies, supporting the participation of companies, to overall support of the process and support of R\&D. The different political measures hence provide different incentives.

The public organisation as the procurer acts as a market driver and hence facilitates incentives for companies to participate. The cases indicate that financial support to the companies helps stimulate their participation in long development processes where it is not certain that the process will get a commercial result. It spurs their interest to participate as their participation is not solely financed by the companies themselves. Another measure that the cases have illuminated is when the public organisation uses its resources to buy the first results of the innovative collaboration.

Another kind of political measures that the cases have highlighted is the use of legal counseling. All of the cases have found a solution to dealing with the legal issues however with different measures. These measures range from the re-organising of procurement units to have procurement lawyers and innovation agents together, to buying additional legal assistance from private law firms, and to including legal assistance from special public programmes assigned to assist public agencies. The legal approach is influenced by the size of procurement units and thus also the legal resources and competences available. To further strengthen the implementation of innovative procurement it will be central to upgrade the legal and procurement skills in procurement units. This could be done through collaboration between small procurement units or by strenthening competences in larger procurement units. It is important that these measures are done in way that ensures innovative procurement.

\section{Need for increased knowledge sharing across the Nordic countries}

Most of these cases in this study are at a very initial phase and to some extent they are pioneers within their country. Since there is an aspiration in all of the Nordic countries to enhance the level of innovation in procurement, there is a need to disseminate examples of good practices and share knowledge and experiences as to what works. This is relevant in relation to all four themes in this report and thus share knowledge on how to navigate the legal framework, how to provide incentives to participate in innovative procurement, how to design the process with the use of dialogue and how to deal with risks. Specifically, there is a call for examples of collaboration agreements, innovative procurement designs and specification requirements that can serve as inspiration or guiding instruments for others wishing to get started. 


\section{Build a bridge between innovation and procurement practices}

A key finding across all Nordic countries is the ambition to do innovative procurements, but at the same time a reality of cost cutting through efficient and standardised public procurement. It is the perception that there is a greater potential in innovative procurement if it becomes a priority in procurement units. In Norway, they are working with different structures to ensure this. A key element is that innovation through procurement is anchored at the top level in public organisations and that it becomes a strategic priority which the organisation is held accountable for. Also, those responsible for carrying out procurements need to have the backing of the top management. If innovative procurement does not become the priorities of the top, it will depend on the efforts of passionate employees as it appears to be the case in many Nordic public organisations.

\section{Cross-Nordic potential}

The study indicates that once innovative procurement has been successfully completed there is a great potential in the marketing of the product or service to other health institutions across borders. The potential among other things is related to the proof of concept demonstrated by the public partner. Based on the insights from the cases, it appears that there is limited experience in participating in innovative procurement processes across the Nordic countries. It is however in the interest of companies that once they have gathered more experience in participating in innovative procurements in their home country, they consider it an untapped opportunity to participate in cross Nordic innovative procurement. Hence, there is a potential in strengthening the opportunities for companies to participate in procurement processes in the other Nordic countries. In this regard, it is important that the invitation to participate in innovative procurement is announced through databases and homepages that ensure bids from national and international companies. 


\section{Sammenfatning}

Denne rapport omhandler innovative indkøb inden for sundhedssektoren i de nordiske lande. Innovative indkøb adskiller sig fra traditionelle indkøb ved at have fokus på at understøtte innovation gennem tilrettelæggelsen af indkøb. Innovative indkøb er dog forbundet med udfordringer, der skal overkommes for at indfri potentialet. Barriererne omfatter udfordringer forbundet med at navigere i det juridiske regelværk, at der i sundhedssektoren i Norden foretages store besparelser, at der er begrænset brug af dialog ved offentlige udbud, at kompetencer til gennemførelse af innovative indkøb er begrænsede samt at der begrænsede incitamenter til at foretage innovative indkøb. Formålet med denne rapport er at øge vidensniveauet for, hvordan barriererne kan overvindes ved at præsentere eksempler på best practice i de nordiske lande. Rapporten er udarbejdet af DAMVAD.

De nordiske eksempler er fra både det regionale og kommunale niveau ligesom de demonstrerer forskellige niveauer i gennemførelse af faserne i innovative indkøb. De nordiske best practices viser, at det trods udfordringer er muligt at gennemføre innovative indkøb samt, at der er fordele forbundet hermed. Centrale fund fra rapporten omfatter:

- Dialog mellem udbyder og tilbudsgiver giver bedre kommunikation om den offentlige sektors behov, samt hvilken viden og innovationsmuligheder, de ligger inde med

- Innovative indkøb giver flere fordele, men medfører også ekstra omkostninger i forhold til øget tids- og ressourceforbrug

- Håndtering af de juridiske rammer er afgørende for gennemførelse af innovative indkøbsproces, men det kan lade sig gøre

- Risici er en iboende del af innovation og dermed også innovative indkøb. De nordiske eksempler har vist forskellige, men overordnede vellykkede tilgange til håndtering af risici

- Der er potentiale $i$, at nordiske virksomheder kan indgå i innovative indkøbsprocesser på tværs af de nordiske lande.

Rapporten viser, at der i alle de nordiske lande er ønske om at udbrede anvendelsen af innovative indkøb i sundhedssektoren som en måde til både at levere bedre ydelser og øge effektiviteten, samt skabe et erhvervsmæssigt potentiale for sundhedsvirksomheder. Der er behov for at dele viden på tværs af norden samt udforme vejledninger til gennemførelse af innovative indkøb med særlig fokus på håndtering af udbudsjura, valg af udbudsmodel samt risikohåndtering. 



\section{Appendix: Methodology}

This chapter examines the methodological basis for the project. The main elements in the methodology are desk research, survey, expert interviews and case interviews.

The main purpose of the study was to identify best practices from the five Nordic countries. This called for a methodology that was specifically designed to identify best practice and overcome the challenges related to limited knowledge on what defines best practices. When searching the literature and the debate about public procurement a great diversity of knowledge is presented, but the identification of best practice cases is seldom done. Different methodologies were applied at different stages to ensure the identification of best practice. The combination of methods ensured that the analysis reached beyond what lies on the discursive level and instead identify specific practices that are recognized as best practice among procurement peers. The proposed methodology design hence considers the risks in addressing real best practice by combining the different methods. The content of the different methodological elements will be elaborated below.

\section{Desk-research}

The first element in the study was a desk research covering the existing knowledge from the Nordic countries. The focus of the desk research was on three main issues:

- Identification of the organisational structure of the public sector within health care in municipalities, regions or governmental level in each of the Nordic countries

- Identification of the organisations with responsibility for procurement in each of the Nordic countries

- Mapping the market and key players (who are the suppliers and buyers, policy makers, developers of procurement tools etc.)

\section{Survey}

Following the desk research, a survey was conducted among procurement experts and practitioners in the five Nordic countries. The main purpose of the survey is to get inputs to the identification of best practices in the Nordic countries with emphasis on risk management, incentives and national perception of the legal framework for procurement. Another purpose was to get supplemented knowledge for the mapping of procurement practices.

The survey was distributed to a vast number of key players within public procurement representing both the public and the private sector in order to ensure that the cases of best practice were identified based 
on a substantial basis. Table 1.1 shows that the survey reached out to a significant number of relevant actors.

\begin{tabular}{lc} 
Table 1.1: Respondents & Initial respondents \\
\hline Country & 24 \\
\hline Denmark & 25 \\
Finland & 34 \\
Iceland & 23 \\
Norway & 33 \\
Sweden & 139 \\
Total & \\
\hline
\end{tabular}

Source: DAMVAD, 2011

To further increase the amount of respondents and thereby come closer to identifying best practice cases, a snowballing technique was implemented. The initial 139 respondents were encouraged to refer to other professionals with relevant knowledge about best practice examples within the four central themes of the study. In total, 32 respondents were added to the survey.

\section{LinkedIn}

To further attract professionals within the field of innovative public procurement in the health sector, the survey was distributed to selected groups with a specific focus on public procurement on the social network website LinkedIn. Table 9 shows the names of the LinkedIn groups, which countries they were related to and the number of group members belonging to the groups.

Table 1.2: LinkedIn groups for survey

\begin{tabular}{llr}
\hline Country & LinkedIN group & Group members \\
Denmark & Offentlig Privat Samarbejde omkring velfærdsopgaver & 98 \\
Denmark & Indkøbsanalyse i den offentlige sektor & 188 \\
Denmark & Professionelle indkøbere - Denmark & 504 \\
Denmark & Offentlige udbud - Denmark & 2277 \\
Europe & PEPPOL (Pan-European Public Procurement Online) = Public Procure- & 690 \\
& ment for the Future & 1166 \\
Europe & Procurement in Government and Public Sector & 1294 \\
Finland & European Public Procurement Network & 52 \\
International & Julkiset hankinnat Suomessa (Public procurement in Finland) & 543 \\
Norway & Offentlige anbud, anskaffelser \& innkjøp - Norway & 81 \\
Sweden & Offentlig upphandling - Sverige & 393 \\
Total & & $\mathbf{7 2 8 6}$ \\
\hline
\end{tabular}

Source: DAMVAD, 2011

An invitation to the online survey was posted in the selected groups. The invitation led to small debates and comments initiated on LinkedIn with referrals to relevant experts and relevant cases. The Danish best practice case was disclosed through a reference on LinkedIn. 


\section{Interviews}

Another central element of the study's methodology was interviews. Two kinds of interviews were conducted; 1) Background interviews with experts and practitioners and 2) Case interviews with representatives of the selected cases.

First of all, a magnitude of 17 background interviews with experienced actors within the field was conducted, cf. table 1.3 below.

\begin{tabular}{lll}
\multicolumn{2}{l}{ Table 1.3: List of background interviews } & \\
\hline Country & Interview person & Organization \\
\hline Iceland & Gunnar Olafsson & Ministry of Welfare \\
Denmark & Jørgen Nielsen & Chefrådgiver, Danske Regioner \\
Denmark & Janni Nielsen & Region Midtjylland \\
Denmark & Max Rolfstam & University of Southern Denmark \\
Denmark & Marie Louise Thomsen & Region Midtjylland \\
Finland & Suzan Ikavalko & Culminatum \\
Finland & Martti Hirvensalo & Hospital District of Helsinki \\
Finland & llona Lundström & Tekes \\
Sweden & Stefan Jönsson & Swedish Competition Authority \\
Sweden & Klas Danerlöv & SKL \\
Sweden & Lars Wilander & Region Skåne \\
Sweden & Björn Lagnevik & Näringslivsutvecklare, Region Skåne \\
Norway & Tore André Sines & Leverand $\varnothing$ rutviklingsprogrammet \\
Norway & Per Harb & Næringslivets Hovedorganisajon (NHO) \\
Norway & Arnhild Gjønnes & Næringslivets Hovedorganisasjon (NHO) \\
\hline Source: DAMVAD 2011 &
\end{tabular}

The purpose of the background interviews was to get insight in the national market structures and to assist the identification of best practice. In combination with the previously described desk research and survey, the interviews ensured an in-depth analysis of innovative public procurement within the health sector and the identification of six cases of real best practice.

Table 1.4 presents the respondents from the best practice cases. The focus in the interviews was on the four central themes Process and Dialogue, Risk management, Incentives and the Legal Framework. In addition, the respondents were asked to reflect upon their overall experiences which gave further knowledge of best practice. 
Table 1.4 List of respondents from best practice cases

\begin{tabular}{|c|c|c|c|}
\hline Best practice case & Country & Persons & Organization \\
\hline PVC-free Blood Bags & Sweden & $\begin{array}{l}\text { Lena Stigh } \\
\text { Gunilla Falk }\end{array}$ & $\begin{array}{l}\text { The Jegrelius Institute for Applied Green } \\
\text { Chemistry } \\
\text { Region Västra Götaland }\end{array}$ \\
\hline The Core Laboratory & Iceland & Halldór Sigurđsson & University Hospital \\
\hline $\begin{array}{l}\text { The Intelligent Hospital } \\
\text { Bed }\end{array}$ & Denmark & $\begin{array}{l}\text { Jacob Pedersen } \\
\text { Jens Bay }\end{array}$ & $\begin{array}{l}\text { Randers Regionshospital } \\
\text { K.R. Hospitalsudstyr }\end{array}$ \\
\hline $\begin{array}{l}\text { Meal Serv ices for the } \\
\text { Elderly }\end{array}$ & Sweden & Hans Knutson & Skåne Food Innovation Network \\
\hline Care+ & Norway & $\begin{array}{l}\text { Eva Hurtig } \\
\text { Kathrine Myhre } \\
\text { Roger Sletta }\end{array}$ & $\begin{array}{l}\text { Oslo Kommune } \\
\text { Oslo MedTech } \\
\text { Hospital IT }\end{array}$ \\
\hline $\begin{array}{l}\text { Supported housing } \\
\text { services }\end{array}$ & Finland & Satu Siikander & The Social Welfare Department of Vantaa \\
\hline
\end{tabular}

Source: DAMVAD, 2011. 
Nordic Council of Ministers

Store Strandstræde 18

DK-1255 Copenhagen K

www.norden.org

\section{Innovative Public Procurement and Health Care}

Nordic Lighthouse Project

This report focuses on the use of innovative procurement in the health sector in the Nordic countries. It presents six Nordic cases demonstrating best practice within innovative procurement. The report argues that despite challenges particularly relating to navigating the legal framework, there are benefits associated with the use of innovative procurement. The use of dialogue between procurers and suppliers is highlighted as a key benefit in innovative procurement as it leads to increased knowledge of possibilities available in the market and hence better solutions. As innovative procurement practice is still relatively new across the Nordic countries, there is a need to disseminate best practices and to develop procurement guides to assist the implementation. The report has been prepared by DAMVAD. 